Hwang, S., Cho, Y. and Shin, J. (2016) 'Does illiquidity matter in residential properties?', Applied Economics, 49 (1), pp. 1-20.

DOI: https://doi.org/10.1080/00036846.2016.1189506

This document is the authors' Accepted Manuscript.

License: https://creativecommons.org/licenses/by-nc-nd/4.0

Available from RADAR: https://radar.brookes.ac.uk/radar/items/7007c139-19d3-477b-aa11-78537e91509c/1/

Copyright (C) and Moral Rights are retained by the author(s) and/ or other copyright owners unless otherwise waved in a license stated or linked to above. A copy can be downloaded for personal non-commercial research or study, without prior permission or charge. This item cannot be reproduced or quoted extensively from without first obtaining permission in writing from the copyright holder(s). The content must not be changed in any way or sold commercially in any format or medium without the formal permission of the copyright holders. 


\title{
Does illiquidity matter in residential properties?
}

\author{
Soosung Hwang ${ }^{1}$ \\ Sungkyunkwan University \\ Youngha Cho ${ }^{2}$ \\ Oxford Brookes University \\ Jinho Shin ${ }^{3}$ \\ Sungkyunkwan University
}

\begin{abstract}
No, it does not, despite the general perception that illiquidity matters in real estate. As expected, our evidence shows that the illiquidity costs for U.S. residential properties are large. The costs are equivalent to $12 \%$ of the total property returns on average, ranging from $9.5 \%$ to $29.5 \%$ of property prices depending on the illiquidity level and market conditions. However, when amortized by holding periods, monthly illiquidity costs are on average $0.08 \%$, and illiquidity risk does not appear to be priced in residential properties; illiquid properties do not show higher returns than liquid properties. On the contrary, we find evidence of flight-toquality in bull markets, i.e., high quality illiquid properties are preferred to low quality liquid properties in buoyant markets. These results are in sharp contrast with those in equities and bonds where flight-to-liquidity has been reported when markets are in stress.
\end{abstract}

Keywords: Illiquidity costs, Residential properties, Flight to Quality, Flight to Liquidity JEL codes: R31, G12

\footnotetext{
${ }^{1}$ Department of Economics, Sungkyunkwan University, 25-2 Sungkyunkwan-ro, Jongno-gu, Seoul 110-745, South Korea. Tel: +82 (0)2 760 0489, Fax: +82 (0)2 744 5717, Email: shwang@skku.edu.

2 Department of Real Estate and Construction, Oxford Brookes University, Gipsy Lane. Oxford, OX3 0BP, UK, Tel: +44(0)1865 483941, Fax: +44(0)1865 483927, Email: ycho@brookes.ac.uk

${ }^{3}$ Corresponding author: Department of Economics, Sungkyunkwan University, 25-2 Sungkyunkwan-ro, Jongno-gu, Seoul 110-745, South Korea. Tel: +82 (0)2 3788 2334, Fax: +82 (0)2 3788 2350, Email: jinho.shinn@gmail.com.
} 


\section{Introduction}

The effects of illiquidity on asset returns have been extensively investigated in the literature. It is well documented that less liquid assets are compensated with higher returns in financial markets (e.g., Amihud and Mendelson, 1986; Amihud, 2002; Pastor and Stambaugh, 2003; Acharya and Pedersen, 2005). In real estate markets, illiquidity risk has also been shown to be priced (Lippman and McCall, 1986; Krainer, 2001; Anglin, 2003; Lin and Vandell, 2007; Bond, Hwang, Lin, and Vandell, 2007; Kawaguchi, Sa-Aadu, and Shilling, 2007; Krainer, Spiegel, and Yamori, 2010).

Most studies, however, focus on the effects of illiquidity on commercial properties; yet, few previous studies have investigated on the effects of illiquidity on residential properties. This paucity of studies may be due to the unattractiveness of residential properties as investments (e.g., Krainer, Spiegel, and Yamori, 2010), or because the costs related to illiquidity are amortized through a relatively longer holding period (Aiyagari and Gertler, 1991; Bond, Hwang, Lin, and Vandell, 2007; Clark, Deurloo, and Dieleman, 2003). For example, only $0.05 \%$ of UK residential properties are covered by the Investment Property Databank (IPD) UK Residential Investment Index, whereas $35.6 \%$ of commercial properties are held by institutional investors, such as REITS. ${ }^{4}$

Considering that residential properties are attracting more institutional investors as an investment vehicle and that a significant proportion of household net worth consists of properties, it becomes increasingly important to investigate the illiquidity costs of residential properties along with their effects on residential property prices. According to a recent survey by Pam Craddock (2013), the majority of institutional investors plan to increase their

\footnotetext{
${ }^{4}$ Investing in residential property, February 2013, British Property Federation.
} 
investment in residential properties to improve their portfolio returns or to diversify their portfolios because of the low correlation of residential properties with other asset classes. ${ }^{5}$ From the households' perspective, residential properties consist of a significant proportion of their wealth portfolios, e.g., primary residential property amounts to $42 \%$ of the median home owner's wealth in the U.S. (The Survey of Consumer Finances, 2010) and, in the UK, the proportion of home equity with respect to the net household worth was $61 \%$ in 2013 (Office for National Statistics, UK).

In this study, we estimate the illiquidity costs of residential properties and then investigate how the illiquidity risk affects residential property returns during bull and bear markets. To our knowledge, the illiquidity of residential properties has not been analysed and, thus, our study fills such gap in the existing literature. In our analysis of residential properties, the dwelling benefits are added to the capital gains because they are considered an important component of a household's utility in owner-occupied residential properties (e.g., Piazzesi, Schneider, and Tuzel, 2007; Flavin and Nakagawa, 2008) as well as for institutional investors. $^{6}$

The effects of illiquidity on residential property prices are investigated using a consumptionbased asset pricing model as in Goswami and Tan (2012) and Olkarinen and Kahra (2002). Our model is an extended version of the liquidity adjusted CAPM of Acharya and Pedersen (2005), where dwelling benefits as well as illiquidity costs of the individual property and the

\footnotetext{
${ }^{5}$ Survey of Institutional Attitudes and Investment in UK Residential Property 2013, July 2013, Pam Craddock, Investment Property Forum. Institutions include pension funds, life assurance companies, and property companies, including real estate investment trusts (REITs) as well as other financial institutions.

${ }^{6}$ Owner occupiers of residential properties do not directly receive cash inflow (rental income), but rather enjoy the equivalent benefits by living in the properties, whereas institutional investors obtain cash flow from renting their properties.
} 
market are considered. Thus, our model guides us on how an individual residential property should be valued with respect to illiquidity risk.

Our empirical analysis consists of two steps. In the first step, we estimate illiquidity costs of residential properties. Although it is widely accepted that residential properties are highly illiquid, there are few studies that directly estimate their illiquid costs. In the second step, these illiquidity costs are incorporated into the consumption-based asset pricing model to investigate if illiquidity risk matters in residential properties. For the analysis we use the S\&P/Case-Shiller Home Price Indices for 16 Metropolitan Statistical Areas in the U.S. from February 1993 to August 2012. The rent-price ratio of Davis, Lehnert, and Martin (2008) is used for dwelling benefits because it can be interpreted as the price of the dwelling benefits agreed upon between landlords and the tenants in the residential property market. To test the robustness of our results, we also use sentiment indices for buying and selling houses as well as for various other macroeconomic variables, following Ling and Naranjo (1997) and Cho, Hwang, and Lee (2014).

In the first step, the illiquidity costs of residential properties are estimated by aggregating the following two components: realtor commission and the cost of immediacy (Grossman and Miller, 1988). These gross illiquidity costs are $16.81 \%$ for illiquid properties and $9.83 \%$ for liquid properties. As in Acharya and Pedersen (2005), these gross illiquidity costs are amortized over holding periods (Clark, Deurloo, and Dieleman, 2003) to obtain the monthly illiquidity costs, which range from $0.06 \%$ to $0.08 \%$ per month for liquid properties, and from $0.09 \%$ to $0.17 \%$ per month for illiquid properties, depending on property markets conditions. The dynamics of illiquidity costs are calculated by normalizing the popular Amihud (2002) measure, i.e., the sum of the ratios of the absolute residential property returns with respect to 
sales pair counts.

The average returns of residential properties from 1993 to 2012 were $0.64 \%$ per month for illiquid properties and $0.62 \%$ per month for liquid properties, $43 \%$ of which came from price appreciation (capital gains). The proportion of price appreciation in the total return of residential properties is different from that in commercial properties where capital gains were only $10 \%$ of the total return for a similar period. ${ }^{7}$ The illiquidity costs we estimate reduce the monthly total returns by $0.10 \%$ per month for illiquid properties and $0.06 \%$ per month for liquid properties; thus, the monthly returns become $0.53 \%$ per month for illiquid properties and $0.57 \%$ per month for liquid properties.

Interestingly, we find that illiquid properties perform better than liquidity properties; the annual Sharpe ratios of illiquid and liquid properties are 2.02 and 1.54 , respectively. The outperformance of illiquid properties is primarily due to their lower volatilities: the monthly standard deviations of illiquid and liquid property returns are $0.91 \%$ and $1.27 \%$, respectively. These Sharpe ratios are comparable with those of commercial properties (Bond, Hwang, and Marcato, 2012), and are higher than those of other alternative investments, such as equities, hedge funds, infrastructure, and commodities (Bond, Hwang, Lin, and Vandell, 2007), which would motivate institutional investors for their growing interests in the housing market.

Our empirical results in the second step, regarding the effects of illiquidity risk on residential property prices, show that illiquidity does not matter in residential properties. This is in sharp contrast with the empirical results in other asset classes, e.g., the U.S. equity and bond

\footnotetext{
${ }^{7}$ The NCREIF total average return for the 20 years up to the third quarter of 2012 was $8.6 \%$ per year, of which the average rental income was $7.7 \%$ each year.
} 
markets where illiquidity is priced (Acharya and Pedersen, 2005; Longstaff, 2004; Beber, Brandt, and Kavajecz, 2009; Acharya, Amihud, and Bharath, 2013). We find that illiquidity is not important in residential markets because neither illiquidity premium nor flight-toliquidity is found in residential properties. ${ }^{8}$ First, there is no empirical evidence that households require a risk premium on the illiquid residential properties during bull markets. On the contrary, the aggregated illiquidity betas of the illiquid residential properties are lower than those of the liquid residential properties during bull markets. Second, we find evidence of flight-to-quality in the residential property markets during bull markets, i.e., high quality illiquid properties are preferred to low quality liquid properties. If liquid assets are preferred to avoid illiquidity risk as market liquidity dries up, we have evidence of flight-to-liquidity. Therefore, although the gross illiquidity costs of illiquid properties are significantly higher than those of liquid properties, these gross illiquidity costs are spread over long holding periods in residential properties (Clark, Deurloo, and Dieleman, 2003) and thus the effects of illiquidity on property prices are minimal.

The layout of this paper is as follows. In the following section, we first derive a consumptionbased CAPM with illiquidity costs and dwelling benefits. In section 3 , illiquidity costs are estimated. In section 4, we investigate whether illiquidity risk is priced in residential property markets. Section 5 concludes.

\section{Pricing residential properties with illiquidity and dwelling benefits}

We propose an asset pricing model in the presence of illiquidity and dwelling benefits by extending the work of Acharya and Pedersen (2005). Our model demonstrates how the two

\footnotetext{
${ }^{8}$ Flight-to-liquidity refers to the preference of investors for liquid assets in order to reduce the illiquidity risk when liquidity dries up.
} 
main characteristics of residential properties, i.e., illiquidity and dwelling benefits, should be considered when pricing residential properties.

\subsection{Residential property pricing model}

Residential properties have a few distinct characteristics that differ from other financial assets: i.e., dwelling benefits and illiquidity. First, dwelling benefits should be included as an argument in the household's utility function because residential properties are consumption goods as well as investment goods as in the literature on asset pricing (e.g., Piazzesi, Schneider, and Tuzel, 2007; Flavin and Nakagawa, 2008). ${ }^{9}$ As in Fisher, Geltner, and Pollakowski (2007), we assume that dwelling benefits are proportional to house prices because the dwelling benefits of expensive houses are expected to be larger than those of less expensive houses. Second, it is well-documented that real estates are illiquid (e.g., Case and Shiller, 1989; Krainer, 2001). Many studies in finance and real estate literature propose various pricing models for illiquidity in assets (e.g., Acharya and Pedersen, 2005; Lin and Vandell, 2007; Flavin and Nakagawa, 2008). These studies reveal that illiquid assets should be compensated with higher expected returns. Illiquidity costs include opportunity costs by delayed trading or additional marketing costs, such as commission fees (e.g., Duffie, Garleanu, and Pedersen, 2002). Third, the relative importance of dwelling benefits and illiquidity in pricing residential properties may not be similar to that in pricing commercial properties, although commercial properties are also characterized by similar features.

Because a residential property is a consumption good as well as an investment good, it is intuitive and appropriate to use the consumption-based asset pricing model to smooth the

\footnotetext{
${ }^{9}$ For institutional investors, dwelling benefits represent rental income.
} 
capital gains and dwelling benefits over the life-cycle and to explain residential property prices. As in typical consumption-based asset pricing, a representative agent (household) who aggregates individual preferences lives for and trades in a single period from $t$ to $t+1$, and derives utility from consumption at each time (see Campbell, 2003; Mehra, 2012). When the household decides consumption at time $t$ and $t+1$ in order to maximize its utility, the expected utility can be described as follows:

$$
E_{t}\left[U\left(C_{t}, C_{t+1}\right)\right]=U\left(C_{t}\right)+\rho E_{t}\left[U\left(C_{t+1}\right)\right],
$$

where $C_{t}$ and $C_{t+1}$ represent the consumptions at time $t$ and $t+1$, respectively; $\rho$ is the subjective discount factor; and $E_{t}[\cdot]$ is an expectation operator. After the household decides how much to consume at time $t$, the remaining are used to invest for future consumption. ${ }^{10}$

Suppose that the household receives incomes of $k_{t}$ and $k_{t+1}$ at each time. Let $Q_{t+1}$ represent the illiquidity cost per square foot from selling a residential property and let $d_{t+1}$ represent the proportion of the dwelling benefits relative to its property price. When $p_{t}$ and $w$ are defined as the price per square foot and the square footage of the property that the household invests in, respectively, the consumption levels at time $t$ and $t+1$ are:

$$
\begin{aligned}
& C_{t}=k_{t}-w p_{t}, \\
& C_{t+1}=k_{t+1}+w\left(p_{t+1}-Q_{t+1}\right)+w p_{t} d_{t+1} .
\end{aligned}
$$

The purchased property size $(w)$ is a continuous variable from the point of view of the aggregated representative household although individual landlords decide to buy or sell a unit property. Therefore, the household's problem is:

$$
\text { Max. } V\left(C_{t}, C_{t+1}\right)=U\left(C_{t}\right)+\rho E_{t}\left[U\left(C_{t+1}\right)\right] \text {, }
$$

s.t. $\quad C_{t}=k_{t}-w p_{t}$,

10 See Cochrane (2005) and Acharya and Pedersen (2005) for detailed discussions of the model. 


$$
C_{t+1}=k_{t+1}+w\left(p_{t+1}-Q_{t+1}\right)+w p_{t} d_{t+1}
$$

From this optimization problem, the expected return on a residential property is:

$$
E_{t}\left[r_{t+1}+d_{t+1}-q_{t+1}-r_{t+1}^{f}\right]=\beta E_{t}\left[r_{t+1}^{M}+d_{t+1}-q_{t+1}^{M}-r_{t+1}^{f}\right]
$$

where $q_{t+1}=\frac{Q_{t+1}}{p_{t}}, \beta=\frac{\operatorname{Cov}\left[r_{t+1}^{M}+d_{t+1}-q_{t+1}^{M}, r_{t+1}+d_{t+1}-q_{t+1}\right]}{\operatorname{Var}\left[r_{t+1}^{M}+d_{t+1}-q_{t+1}^{M}\right]}$, and $r_{t+1}^{f}$ are the risk free rates, and the superscript $M$ means the entire market (Refer to the Appendix for proof). The lefthand side of the equation (2) represents the expected excess return on the residential property after considering both illiquidity costs and dwelling benefits.

The pricing model in equation (2) shows a few differences from the conventional CAPM. First, dwelling benefits can play an important role in the expected return. As estimated by Davis, Lehnert, and Martin (2008), the dwelling benefits are significant in residential properties and tend to decrease as property prices increase, and vice versa. Because of their adverse movements to property prices, dwelling benefits would make the total return (i.e., $\left.r_{t+1}+d_{t+1}\right)$ stable over time. These properties of dwelling benefits, however, are in sharp contrast to those of the dividends that shareholders receive by holding equities: firms have become less likely to pay dividends over the past several decades (Fama and French, 2001), whereas dwelling benefits have not shown any trend for the past several decades (Davis, Lehnert, and Martin, 2008).

Second, the expected excess return of a residential property is determined by the conventional systematic risk as well as the betas related to illiquidity. To see this, we further decompose the systematic risk, $\beta$, in equation (2) into the following four betas:

$$
\beta=\beta^{1}+\beta^{2}-\beta^{3}-\beta^{4},
$$

where 


$$
\begin{aligned}
& \beta^{1}=\frac{\operatorname{Cov}\left[r_{t+1}+d_{t+1}, r_{t+1}^{M}+d_{t+1}\right]}{\operatorname{Var}\left[r_{t+1}^{M}+d_{t+1}-q_{t+1}^{M}\right]}, \\
& \beta^{2}=\frac{\operatorname{Cov}\left[q_{t+1}, q_{t+1}^{M}\right]}{\operatorname{Var}\left[r_{t+1}^{M}+d_{t+1}-q_{t+1}^{M}\right]}, \\
& \beta^{3}=\frac{\operatorname{Cov}\left[q_{t+1}, r_{t+1}^{M}+d_{t+1}\right]}{\operatorname{Var}\left[r_{t+1}^{M}+d_{t+1}-q_{t+1}^{M}\right]}, \\
& \beta^{4}=\frac{\operatorname{Cov}\left[r_{t+1}+d_{t+1}, q_{t+1}^{M}\right]}{\operatorname{Var}\left[r_{t+1}^{M}+d_{t+1}-q_{t+1}^{M}\right]} .
\end{aligned}
$$

The first beta, $\beta^{1}$, is equivalent to the conventional CAPM beta, which increases with the expected return. The remaining three betas represent illiquidity-related risks. The second beta, $\beta^{2}$, indicates that the expected return increases with the covariance between the illiquidities of the residential property and the market. Thus, a higher expected return is required for a residential property that becomes illiquid when the market liquidity dries out. On the other hand, the last two betas, $\beta^{3}$ and $\beta^{4}$, suggest that the expected return decreases with the relationship between illiquidity and returns. For example, when market returns are negative and thus, marginal utility increases in bear markets $\left(r_{t+1}^{M}+d_{t+1}<0\right)$, properties with higher illiquid costs should be compensated with higher expected returns. On the other hand, a higher return is expected on a property whose return decreases when the market becomes illiquid (Pastor and Stambaugh, 2003; Chien and Lustig, 2010).

\subsection{Illiquidity costs of residential properties}

Liquidity is a multi-dimensional concept that is characterized by tightness, depth, resiliency, and immediacy (Kyle, 1985; Grossman and Miller, 1988), and thus has been estimated in various ways. Therefore, illiquidity measures that were developed for other asset classes (e.g., various illiquidity measures in equities) may not be appropriate in real estate due to its uneven distribution of information, different characteristics in individual properties, and major roles played by agents and appraisers (e.g., Fisher, Gatzlaff, Geltner, and Haurin, 2003; 
Collett, Lizieri, and Ward, 2003). In order to overcome these difficulties, we calculate the Amihud (2002) measure, and then normalize it by considering the characteristics of residential properties. Therefore, our illiquidity costs $\left(q_{t}\right)$ reflect various aspects of liquidity discussed in financial markets as well as characteristics that are unique to residential properties.

Amihud's (2002) illiquidity measure is calculated using the following equation:

$$
A_{t}=\sum_{i=1}^{I} \frac{\left|r_{i t}\right|}{N_{i t}}
$$

where $\left|r_{i t}\right|$ is the absolute return on the residential property $i$, and $N_{i t}$ is the trading volume of property $i$ at time t. The rationale behind the illiquidity measure is that when residential property prices move significantly for small trading volumes, the residential properties are considered as being illiquid. Several other proxies for illiquidity costs, for example, price impact of trading volume (Pastor and Stambaugh, 2003), turnover (Rouwenhorst, 1999), and bid-ask spread (Stoll, 1978), are possible, but are not used in this study primarily due to the lack of data required for the calculation of these measures.

The Amihud measure needs to be normalized (scaled) because it does not represent the 'cost with respect to price' (i.e., $q_{t}$ ), but simply the 'price change with respect to volume'. Acharya and Pedersen (2005), in their study of illiquidity in equities, normalize the Amihud measure using the transaction price and the midpoint of the prevailing bid-ask quote. For residential properties, however, these data are not available and, thus, we directly calculate illiquidity costs using the following two components in residential properties: sales costs and the cost of immediacy. The illiquidity costs are then amortized over the holding periods of the property in order to calculate the monthly costs (Heaton and Lucas, 1996; Acharya and 
Pedersen, 2005; Bond, Hwang, Lin, and Vandell, 2007).

Sales costs, the first component of illiquidity costs, represent costs that are directly related to the liquidation of properties. The realtor commission paid by the seller to the selling realtor is such costs, and is known to be approximately $6 \%$ of the sales price in U.S. residential property markets (e.g., Salant, 1991; Hendel, Nevo, and Ortalo-Magne, 2009). The second component is the capital loss that occurs when residential properties are to be liquidated in a short period of time. This is closely related to Kyle's (1985) 'tightness' or Grossman and Miller (1988) and Hooker and Kohn's (1994) 'cost of immediacy', because the capital loss represents the cost a household faces by selling now rather than waiting for a better price.

\section{Data and illiquidity costs}

In this section, we explain the data and the details of the estimation method for the calculation of illiquidity costs.

\subsection{Residential property returns and dwelling benefits}

We use the S\&P/Case-Shiller Home Price Indices, which provide three separate monthly indices by price level - low, middle and high - for 16 major Metropolitan Statistical Areas. ${ }^{11}$ According to Clapp and Giaccotto (1992) and Case, Pollakowski, and Wachter (1997), cheaper houses are more liquid because smaller houses are more frequently traded. ${ }^{12}$ Therefore, in this study, we use low and high price tier indices as the liquid and illiquid

\footnotetext{
${ }^{11}$ Among the 17 areas of S\&P/Case-Shiller Home Price Tiered Indices, Cleveland was excluded because Home Price Sales Pair Counts were not available after December 2008. S\&P/Case-Shiller Home Price Indices exclude quality changes in residential properties; hence, low and high tier indices mainly include the liquidity difference. ${ }_{12}$ In equity markets, small stocks are known to be illiquid. For example, Hwang and Lu (2008) report that the correlation coefficient between the returns of size-sorted portfolios and illiquidity sorted portfolios is 0.75 in the U.K. equity market.
} 
residential property price indices, respectively. The difference between these tiered indices also represents the quality difference, the effects of which on residential property prices are controlled using other variables. We return to these control variables later. Our sample period is from February 1993 to August 2012.

Table 1 presents the basic statistical properties of Case-Shiller price tiered index returns in 16 Metropolitan Statistical Areas. The return difference between illiquid and liquid houses is referred to as $I M L$ (Illiquid property return Minus Liquid property return). In panel A, little difference is found in the average returns between illiquid and liquid houses for the entire period. When the entire period is divided into bull and bear housing markets using the May 2006 historic house price peak, however, the average returns of liquid houses were larger than those of illiquid houses in all areas during bull markets until May 2006, when the upward trend in the housing markets was reversed (panel B). On the contrary, in panel C, liquid house prices decrease far more than those of illiquid houses during bear markets after June 2006. The average IMLs during bull and bear periods, i.e., $-0.16 \%$ and $0.39 \%$ per month, respectively, are statistically significant at the 5\% level.

Dwelling benefits are calculated with the rent-price ratio, because the rent-price ratio represents the cost that tenants agree to pay their landlords for dwelling in the properties. The quarterly rent-price ratio of Davis, Lehnert, and Martin (2008) is transformed to a monthly basis by a simple linear interpolation. ${ }^{13}$ The ratios stayed at approximately $0.4 \%$ per month until 2000 , and then decreased to $0.26 \%$ per month at the peak of the house market, primarily

\footnotetext{
${ }^{13}$ Interpolation may induce an auto-correlation problem. Alternatively, the monthly rent-price ratio can be generated using random variables under the assumption that the variance of the monthly rent-price is a twelfth of the variance of the annual rent-price ratio. However, this alternative method does change the results we report in this study. See Cho, Hwang, and Satchell (2012) for another application of the linear interpolation.
} 
due to the sharp upsurge of house prices until 2006. Then, the ratio returned to $0.4 \%$ per month with the recent house price depreciation.

[Table 1 here]

\subsection{Estimation of gross illiquidity costs}

Illiquidity costs are estimated using realtor commission and the cost of immediacy. Although the realtor commission is negotiable between a seller and an agent, it is approximately $6 \%$ of the price in U.S. residential property markets, as in Salant (1991) and Hendel, Nevo, and Ortalo-Magne (2009). However, the cost of immediacy is not straightforward. We estimate the immediacy cost using the price discounts for forced sale after bankruptcy (per month) and the marketing periods for liquid and illiquid properties in bull and bear markets.

The price discounts for forced sale after bankruptcy is a good proxy of the immediacy cost, because the discounts reflect the costs for liquidating properties within short marketing periods. Campbell, Giglio, and Pathak (2011) report that price discounts for forced sales after bankruptcy are on average $5.6 \%$. Considering that the notice of sale of real property should be posted at least 20-30 days immediately preceding the sale, we take one month for the typical marketing time of the forced sale after bankruptcy. ${ }^{14}$

The average marketing period varies significantly depending on market conditions and regions. Carrillo and Pope (2012) report that in Fairfax County, Virginia, the average marketing period is about 2.2 months, but increases to approximately 4.9 months during bear

\footnotetext{
${ }^{14}$ For example, see the codes for publishing the notice of sale of real properties, such as REVISED CODE OF WASHINGTON 6.21.030, NORTH CAROLINA STATUTES AND CODES 45-21.17, and NEW YORK STATE REAL PROPERTY ACTIONS AND PROCEEDINGS LAW 231.
} 
markets, i.e., 1997, 2006, and 2007. In Columbus, Ohio, however, the average marketing period during bear markets (i.e., from April 1990 to December 1991) is approximately 6.3 months (Glower, Haurin and Hendershott, 1998). Fairfax County is one of the richest and best-educated counties in the U.S. and thus is popular, whereas the popularity of Columbus is in the middle among large metropolitan areas. ${ }^{15}$ Assuming that liquidity increases with popularity, the difference in the marketing periods between Fairfax and Columbus in bear markets, i.e., 1.4 months $(=6.3-4.9)$, can be added to the average marketing period in Fairfax County to obtain the nationwide average marketing period of 3.6 months $(2.2$ month +1.4 month). ${ }^{16}$ Thus, by comparing the loss from the forced sale after bankruptcy $(5.6 \%$, one month marketing period) and ordinary sales (no loss, 3.6 months marketing period), the cost of immediacy per month can be calculated as $2.2 \%(=(5.6 \%-0 \%) /(3.6$ months -1 month $))$.

We next calculate the marketing periods of illiquid and liquid properties in bull and bear markets. The marketing periods for liquid and illiquid properties are obtained by taking the marketing periods at 25 and 75 percentiles of Carrillo and Pope (2012), respectively, because liquid properties require shorter marketing periods compared to illiquid properties. In addition, the period from 1998 to 2005 of Carrillo and Pope (2012) corresponds to a bull market, whereas other periods, i.e., 1997, 2006, and 2007, correspond to bear markets. Therefore, considering 1.4 months for the difference in marketing periods between Fairfax County and the whole country, marketing periods for illiquid and liquid properties are estimated to be 3.9 and 1.6 months during bull markets, and 10.9 and 2.7 months during bear

\footnotetext{
${ }^{15}$ Ceteris paribus, properties in a popular area are more expensive than those in a less popular area. Davis and Palumbo (2007) report that the average property value in Columbus is ranked 26th among the 46 large metropolitan areas. The average property value in Washington, D.C., which borders Fairfax County, is ranked $7^{\text {th }}$. ${ }^{16} \mathrm{We}$ assume that the nationwide marketing period is the same as that of Columbus. The nationwide average marketing period is the same as the marketing period of 3.6 months, reported by Jud, Seaks, and Winkler (1996) in North Carolina during the period of 1991 to 1993. The U.S. housing market was recovering during this period, following the economic downturn in the early 1990s.
} 
markets, respectively (Panel A of Table 2). Illiquid properties show a large difference in the marketing periods between bull and bear markets, whereas the marketing periods of liquid properties change relatively modestly on market conditions. These are consistent with the results in the literature. For example, Jud, Seaks, and Winkler (1996) report that half of properties are sold within six months and most properties are sold within sixteen months during the end of the bear period. Our results also support that residential properties trade infrequently as their prices increase (Clapp and Giaccotto, 1992), and that the time on market has a positive relationship with the selling price (Knight, 2002).

[Table 2 here]

Panels B, C, and D of Table 2 show the estimated illiquidity costs, including the realtor commission and the costs of immediacy, i.e., the marketing periods times the monthly immediacy cost of $2.2 \%$. The cost of immediacy of illiquid properties varies between $8.40 \%$ and $23.48 \%$, and that of liquid properties varies between $3.45 \%$ and $5.82 \%$, depending on market conditions. The average costs of immediacy are $10.81 \%$ and $3.83 \%$ for illiquid and liquid properties, respectively. ${ }^{17}$

In order to investigate the robustness of our estimates, we perform a few additional tests. First, the cost of immediacy per month increases to $2.9 \%$ (or decreases to $1.7 \%$ ) when the difference in the marketing periods between Fairfax County and the whole country decreases

\footnotetext{
${ }^{17}$ In order to calculate the average illiquidity costs for the entire sample period, we first estimate proportions of transactions in a month during bull and bear markets using the marketing periods in panel $\mathrm{A}, 71.11 \%$ and $28.89 \%$, respectively, under the assumption that property sales follow the Poisson distribution (Bond, Hwang, Lin, and Vandell, 2007). These proportions are then multiplied by the number of bull and bear months in our sample periods, 160 and 75 months, respectively. Therefore, the weights on bull and bear markets are $84.0 \%$ and $16.0 \%$, respectively.
} 
to 0.7 months (or increases to 2.1 months). However, we find that our results on the effects of illiquidity risk on residential property prices hold regardless of these immediacy costs. The main reason is that the illiquidity costs are used to normalize the Amihud measure, and thus the dynamics of illiquidity costs is driven by the Amihud measure. Second, despite the differences in the definition of illiquidity costs, our estimates are largely similar to other estimates, in particular, those of Lin and Vandell (2007). They suggest $\sqrt{3} E(T) \sigma_{T}$ for liquidation bias, where $E(T)$ and $\sigma_{T}$ represent the expected marketing period and the transaction volatility, respectively. We estimate liquidation biases for liquid and illiquid properties, which are $2.3 \%$ and $5.5 \%$ during bull markets and $10.3 \%$ and $27.0 \%$ during bear markets, respectively. ${ }^{18}$ Although the approaches are quite different, the illiquidity costs from immediacy and liquidation bias are similar, indicating the robustness of our estimation.

\subsection{Amortization of gross illiquidity costs}

The gross illiquidity costs, i.e., the realtor commission and the cost of immediacy, should be amortized over the holding periods of residential properties (Constantinides, 1986; Aiyagari and Gertler, 1991; Heaton and Lucas, 1996; Acharya and Pedersen, 2005; Bond, Hwang, Lin, and Vandell, 2007), because illiquidity costs do not occur every month. ${ }^{19}$ Clark, Deurloo, and Dieleman (2003) report that the average period during which a household stays in a property depends on the price of the property; U.S. households stay in the same residential properties for 138 and 160 months, on average, for low and high value residential properties, respectively. These periods are used to amortize the gross illiquidity costs.

Panels B, C, and D of Table 2 summarize the estimated monthly illiquidity costs. As expected,

\footnotetext{
18 These results can be obtained from the authors upon request.

19 Acharya and Pedersen (2005) assume 29 months as the average holding period for equities.
} 
the amortized illiquidity costs of illiquid properties are higher than those of liquid properties in spite of their longer amortization periods. Between liquid and illiquid properties, the amortized monthly illiquidity costs range from $0.06 \%$ per month to $0.08 \%$ per month for liquid residential properties (Panel C), and from $0.09 \%$ per month to $0.17 \%$ per month for illiquid residential properties (Panel D). During bull markets, the monthly illiquidity costs of illiquid properties are approximately $0.03 \%$ per month higher than those of liquid properties, whereas the difference increases to $0.09 \%$ per month during bear markets. The illiquidity costs of illiquid properties increase far faster than those of liquid properties during the bear period.

\subsection{Monthly illiquidity costs of residential properties}

As aforementioned, the illiquidity measure of Amihud (2002) in (7) should be normalized with respect to the illiquidity costs in order to reflect the dynamics of illiquidity in property markets, e.g., seasonal patterns in liquidity. The measure is calculated using sales pair counts in the denominator because the trading volumes in dollar amounts are not available for the Case-Shiller index.

Using the ranges of illiquidity costs in Table 2, we normalize the Amihud measure in order to obtain the illiquidity costs for illiquid properties $\left(q_{t}^{H}\right)$, liquid properties $\left(q_{t}^{L}\right)$, and whole residential properties $\left(q_{t}^{M}\right)$ :

$$
\begin{aligned}
& q_{t}^{H}=\operatorname{Max}\left\{0, \operatorname{Min}\left(-0.00050+0.51 \times A_{t}, 0.29 \%\right)\right\}, \\
& q_{t}^{L}=\operatorname{Max}\left\{0, \operatorname{Min}\left(-0.00015+0.25 \times A_{t}, 0.10 \%\right)\right\}, \\
& q_{t}^{M}=\operatorname{Max}\left\{0, \operatorname{Min}\left(-0.00015+0.30 \times A_{t}, 0.29 \%\right)\right\} .
\end{aligned}
$$

The parameters in the equations above are chosen to match the Amihud measure to the 
average illiquidity costs in Table 2 with preserving its volatility. ${ }^{20}$ The upper limit is set to the maximum illiquidity costs, which minimizes the possibility that our results are driven by the extreme values of the Amihud measure. To check the robustness of this normalization method, we also calculate two other illiquidity costs as follows:

$$
\begin{aligned}
& q_{t}^{H^{\prime}}=\operatorname{Max}\left\{0, \operatorname{Min}\left(-0.00070+0.55 \times A_{t}, 0.29 \%\right)\right\}, \\
& q_{t}^{L^{\prime}}=\operatorname{Max}\left\{0, \operatorname{Min}\left(-0.00065+0.38 \times A_{t}, 0.10 \%\right)\right\}, \\
& q_{t}^{M^{\prime}}=\operatorname{Max}\left\{0, \operatorname{Min}\left(-0.00055+0.40 \times A_{t}, 0.29 \%\right)\right\}, \\
& q_{t}^{H^{\prime \prime}}=\operatorname{Max}\left\{0, \operatorname{Min}\left(0.00015+0.27 \times A_{t}, 0.29 \%\right)\right\}, \\
& q_{t}^{L^{\prime \prime}}=\operatorname{Max}\left\{0, \operatorname{Min}\left(0.00005+0.17 \times A_{t}, 0.10 \%\right)\right\}, \\
& q_{t}^{M^{\prime \prime}}=\operatorname{Max}\left\{0, \operatorname{Min}\left(0.00020+0.18 \times A_{t}, 0.29 \%\right)\right\} .
\end{aligned}
$$

Table 3 presents the basic properties of the Amihud measure and the normalized illiquidity costs. The illiquidity costs normalized by the first and third methods have similar means to that in Table 2, i.e., $0.08 \%$ per month. The second method is designed to generate illiquidity costs with a lower mean with higher volatility, whereas the third method is to generate illiquidity costs with a lower volatility. The Amihud measure and these normalized illiquidity costs have similar statistical properties during bull markets. Figure 1 demonstrates that illiquidity costs have increased sharply during the recent bear market. This is consistent with the dynamics of other financial assets in that liquidity decreases during market downturns (Pastor and Stambaugh, 2003).

[Table 3 here]

Illiquidity costs in Figure 1 clearly suggest seasonal patterns. The seasonal patterns, however,

\footnotetext{
${ }^{20}$ Acharya and Pedersen (2005) normalize the Amihud measure using the midpoint of the prevailing bid-ask quote.
} 
are different between bull and bear markets. In panel A of Figure 2, the illiquidity costs during bear markets increase from October and peak in February, and thus are highest during the first quarter. These results are consistent with those in panels $\mathrm{B}$ and $\mathrm{C}$ as well as in the existing literature, indicating the seasonality in the property market. For example, Ngai and Tenreyro (2014) find that both prices and transactions increase during the hot season, i.e., the second and third quarters, but decrease during the cold season, i.e., the fourth and first quarters.

[Figure 1 here]

The seasonality in the illiquidity costs is more prominent during bear periods than during bull periods. For example, in bull markets, the average illiquidity cost is the highest in April. When liquidity dries up during bear markets, illiquidity costs change significantly depending on the hot and cold seasons; the illiquidity cost ranges from $0.07 \%$ to $0.22 \%$ per month in bear markets, whereas it changes from $0.03 \%$ to $0.09 \%$ in bull markets. When property markets are buoyant, illiquidity costs are low and change only slightly with the seasons.

The seasonal patterns of $I M L s$, the return difference between illiquid and liquid properties, are similar to those of illiquidity costs in panel A. Panel D of Figure 2 shows that the variation of patterns becomes large in bear markets. $I M L$ tends to be higher in the first quarter, which then shows a downward trend for the other quarters. Yet, the seasonal pattern in $I M L$ is not found during bull markets; $I M L$ is small and negative regardless of the hot and cold seasons. These results indicate that illiquidity may not matter during bull periods and that the seasonal patterns in residential property markets need to be considered during bear markets. 
[Figure 2 here]

\subsection{Other control variables}

As suggested by many previous empirical studies, property returns are likely to be affected by other factors, in particular, macroeconomic variables (Ling and Naranjo, 1997; Cho, Hwang, and Lee, 2014). In this study, we use several macroeconomic variables that affect residential property prices in addition to the market return. When properly chosen, these variables are expected to explain the cross-sectional return difference between high and low price properties other than illiquidity. Due to the fact that low price properties tend to be traded by low income households rather than by high income households (Clark, Deurloo, and Dieleman, 2003), the difference in property returns between high and low price residential properties may be affected differently by the factors that affect the household income of these two groups.

For these purposes, we select macroeconomic variables: three interest rate-related variables (credit spread, term spread, and mortgage interest rate), economic growth, inflation, and unemployment rate. Credit Spread (CS) reflects the risk premium and is the calculated difference in the bond yields between Moody's Aaa and Baa rated corporate bonds. Term Spread (TS) is the difference in the rates between a 10-year Treasury bond and a three-month Treasury bill. Besides these relative interest-related measures, we also consider 30-year mortgage interest rates (MRTG_RT). If bull markets are fuelled by easier money with low mortgage rates, then buyers may prefer expensive (illiquid) houses. As the major economic variables, we consider the industrial production growth change (IP), CPI change (CPI), and unemployment rate (UNE). These macroeconomic variables are obtained from the St. Louis FRB Economic Data. In addition to these macroeconomic variables, we also include 
consumer sentiments on buying and selling a house, which are provided from the University of Michigan Consumer Sentiment Index. The sentiment indices are standardized to have zero mean and unit variance. ${ }^{21}$

\subsection{Properties of residential property returns and other variables}

Table 4 shows the basic statistical properties and correlations of residential property returns, illiquidity costs, and the control variables. The difference in the average property returns between liquid and illiquid properties is negligible; however, their difference in return volatility is large: the standard deviations of liquid property returns are approximately $30 \%$ larger than those of illiquid properties. Therefore, during the entire period, illiquid residential properties look more attractive because the Sharpe ratio of illiquid properties, i.e., the ratio of the average return to its standard deviation, is significantly higher than that of liquid properties. Further, dwelling benefits increase the average returns by $0.36 \%$ per month without affecting volatility. On the other hand, illiquidity costs reduce the average returns by approximately $0.11 \%$ and $0.05 \%$ per month for illiquid and liquid properties, respectively.

[Table 4 here]

As expected, property returns are negatively related to illiquidity costs, suggesting that illiquidity increases in bear markets. The illiquidity costs have positive correlations with the variables related to risk, such as credit spread and term spread. However, they are negatively correlated with industrial production and positively correlated with the unemployment rate, because higher industrial production or lower unemployment rate implies a better economic

\footnotetext{
${ }^{21}$ We also tried other explanatory variables such as delinquency rate on single-family residential mortgages, mortgage debt service payments as a percent of disposable personal income, and consumer debt service payments as a percent of disposable personal income. These results are not different from those in Table 6 .
} 
condition with more liquidity in property markets. When credit risk or unemployment increases, house prices decrease. Yet, inflation does not show a strong relationship with house prices. These relationships between residential property returns and macroeconomic variables are similar to those between commercial properties and macroeconomic variables, as reported in Cho, Hwang, and Lee (2014). The mortgage interest rate appears to have small positive correlations with residential property returns during the entire period, but the correlations in each sub-period appear to be negative. ${ }^{22}$ Finally, a buy or sell sentiment has negative relationships with the illiquidity costs, because property trades increase with the buying or selling sentiment. First order autocorrelations indicate that most of these variables are highly persistent.

\section{The effects of illiquidity on residential property returns}

In this section we use the monthly illiquidity costs and property returns to estimate illiquidity betas and investigate if illiquidity matters in residential properties.

\subsection{The illiquidity risk and residential property returns}

Table 5 presents the estimates of the betas in equations (3) to (6). Liquid properties have a significantly higher CAPM beta, $\beta^{1}$, compared to illiquid properties. Because liquid properties are less expensive than illiquid ones in this study, our result indicates that less expensive houses are generally riskier investments than expensive houses, particularly during bear markets when the marginal utility is high (panel C). This is comparable with the result that small stocks are riskier than large stocks (Fama and French, 1992).

\footnotetext{
${ }^{22}$ In bullish markets, the correlation coefficients between the mortgage interest rate and the residential property returns are -0.38 and -0.53 for the expensive and cheap properties, respectively. Thus, households who possess cheap residential properties are more sensitive to changes in mortgage interest rate during bull markets. In bearish markets, however, the correlation coefficients are -0.27 and -0.28 for the expensive and cheap properties, respectively.
} 
[Table 5 here]

The positive illiquidity risk, $\beta^{2}$, supports that the required return of residential properties increases with the covariance between property illiquidity and market illiquidity $\left(\operatorname{Cov}\left(q_{t+1}\right.\right.$, $\left.q_{t+1}^{M}\right)$ ), i.e., the commonality in illiquidity (Chordia, Roll, and Subrahmanyam, 2000). Therefore, a household requires a return premium for a property when its illiquidity increases with market illiquidity. The second illiquidity risk, $\beta^{3}$, is negative, suggesting that the covariation between property illiquidity and market return $\left(\operatorname{Cov}\left(q_{t+1}, r_{t+1}^{M}+d_{t+1}\right)\right)$ increases the risk when the negative sign on $\beta^{3}$ is considered. Households require higher returns on residential properties that become more illiquid when market returns decrease. Finally, the illiquidity risk due to the covariance between property returns and market illiquidity costs $\left(\operatorname{Cov}\left(r_{t+1}+d_{t+1}, q_{t+1}^{M}\right)\right), \beta^{4}$, is negative and significant. Together with the negative sign on the negative betas, the required returns increase because households experience lower returns on properties when housing markets become illiquid. These signs of $\beta^{2}, \beta^{3}$, and $\beta^{4}$ are not different from those of equities reported by Acharya and Pedersen (2005).

However, a few distinct differences are found in residential property markets. First, the signs on $\beta^{3}$ and $\beta^{4}$ differ depending on the market conditions: positive values of $\beta^{3}$ and $\beta^{4}$ during bull markets become negative during bear markets. ${ }^{23}$ Positive values of $\beta^{3}$ and $\beta^{4}$

\footnotetext{
${ }^{23}$ Note that $\mathrm{t}$-statistics are not provided for the estimates of $\beta^{2}$ and $\beta^{3}$ because we have only three portfolios (liquid, medium, and illiquid properties); thus, cross-sectional covariances between illiquidity costs of the three portfolios and market returns or between these illiquidity costs and market illiquidity costs could not be calculated. The estimates in Table 5 suggest that differences in the required returns between the different values of $\beta^{2}$ and $\beta^{3}$ are small and are not economically significant.
} 
during bull markets imply that property prices increase with illiquidity, and thus, the illiquidity risk is not priced in bull markets. See section 2.1 for a detailed explanation. Their positive values suggest asymmetric behaviour of property prices due to movement of return and price impact in the same direction. For example, positive values of $\beta^{3}$ make the price impact of properties larger when market returns increase. Interestingly, it appears that illiquid and high-priced residential properties have larger positive values of $\beta^{3}$ and $\beta^{4}$ than the liquid and low-priced properties during bull periods. Thus, the illiquid properties show a stronger co-movement between return and illiquidity, which makes the illiquid properties have higher returns than the liquid properties when the housing market becomes illiquid. This is evidence of "Flight to Quality" (FTQ): households prefer high quality illiquid properties to low quality liquid properties within residential property markets during bull periods. The aggregated illiquidity betas of the illiquid residential properties are lower than those of liquid properties and thus, households are willing to accept lower returns on liquid properties than on illiquid properties in bull markets. More specifically, expensive illiquid properties are preferred to cheap liquid properties. This is in sharp contrast to "Flight to Liquidity".

Second, we find evidence of "Flight to Liquidity" (FTL) within residential property markets during bear periods. The aggregated illiquidity betas $\left(\beta^{\text {Illiq }}=\beta^{2}-\beta^{3}-\beta^{4}\right)$ of illiquid residential properties are larger than those of liquid properties in bear markets. This result indicates that households require lower returns on liquid properties than those on illiquid properties, and thus are consistent with the FTL found in the U.S. equity market (Acharya and Pedersen, 2005) and the U.S. bond market (Acharya, Amihud, and Bharath, 2013). The FTL within residential property markets are driven by $\beta^{3}$, which represents the illiquidity sensitivity to market returns. This implies that liquid residential properties are preferred 
during bear markets in order to minimize the illiquidity risk.

\subsection{The effects of illiquidity risk on residential property returns in the presence of control variables}

Although the decomposition of beta provides useful insight into illiquidity risks in pricing residential properties, the results might be affected by the quality of the properties, because our liquid and illiquid portfolios can also be interpreted as low and high quality properties, respectively. Moreover, the beta is likely to change over time depending on the macroeconomic variables (Ferson and Harvey, 1993; Petkova and Zhang, 2005; Ang and Chen, 2007; Cho, Hwang, and Lee, 2014). In this section, we analyse how residential property prices react to illiquidity in the presence of various control variables, which can explain property prices.

Using macroeconomic variables in the pooled regression, we regress $I M L s$ on market returns, market illiquidity costs, and other control variables:

$$
\begin{aligned}
& I M L_{i t}\left(=r_{i t}^{H}-r_{i t}^{L}\right)=\alpha+\beta r_{t}^{M^{*}}+\gamma q_{t}^{M}+\sum_{k=1}^{K} \theta_{k} f_{k t}+\varepsilon_{i t}, \\
& \varepsilon_{i t}=\varphi_{1} \varepsilon_{i t-1}+\varphi_{3} \varepsilon_{i t-3}+\varphi_{12} \varepsilon_{i t-12}+\eta_{i t},
\end{aligned}
$$

where $r_{t}^{M^{*}}=r_{t}^{M}+d_{t}-r_{t}^{f}, q_{t}^{M}$ is the market illiquidity cost, $f_{k t}$ represents the macroeconomic variables and a cold season dummy, and $\varepsilon_{i t}$ is the idiosyncratic error that explains persistence as well as the seasonal patterns in residential property markets. The first lag in the autoregressive process is for the persistence of residential property returns; the other two lags, 3 and 12, are for the seasonality of property returns, which we report in Figure 2. Note that in the pooled regression, the number of cross-sectional units is 48 (high, medium, and low price levels for each of the 16 Metropolitan Statistical Areas). In equation (8), FTQ exists when the 
coefficient on market illiquidity costs, i.e., $\gamma$, is positive, because a positive $\gamma$ captures preference toward illiquid properties with respect to the market illiquidity. On the other hand, FTL exists if $\gamma<0$.

Table 6 reports the estimation results of equation (8) for the whole sample period as well as for the bull and bear markets. To check the impacts of the normalization method, we also consider the other two normalized illiquidity costs, i.e., $q_{t}^{\prime}$ and $q_{t}^{\prime \prime}$. Overall, the three methods for normalizing illiquidity costs, in general, show little differences.

\section{[Table 6 here]}

The results in Table 6 support FTQ during bull markets, which we report in Table 5. In the bull market, large and positive coefficients on market illiquidity costs mean that the illiquid property prices increase more than the liquid property prices in response to illiquidity increases, thereby indicating a relative preference toward illiquid properties. The FTL phenomenon in the bear market that we report in Table 5, however, appears to be insignificant in the presence of the control variables. ${ }^{24}$ Therefore, the illiquidity risk does not matter in the residential property markets.

The residential property returns can be explained by the market return, seasonality, and illiquidity costs. Some other control variables also appear to be significant. For example, term spread, unemployment rate, and sentiment on buying a house are significant for $I M L$ s in bull markets. Because a term spread negatively affects $I M L \mathrm{~s}$, the illiquid property returns benefit

\footnotetext{
${ }^{24}$ Due to the structural break before and after May 2006, we focus on the results of bull and bear periods rather than those of the entire period. The log likelihoods for the entire period, bull market, and bear market models are $-5097.17,-2289.39$, and -1887.05 , respectively, suggesting a statistically significant structural break.
} 
more than the liquid property returns, as the term spread decreases in bull markets. As unemployment rate appears to decrease $I M L \mathrm{~s}$, the liquid property returns increase more than the illiquid property returns due to lower unemployment rate in bull markets. This result implies that the households who possess cheap residential properties are more sensitive to unemployment rate. Moreover, the sentiment on buying a house has a positive relationship with $I M L s$ in the bull markets, suggesting that a positive sentiment leads to a return increase of expensive houses more than that of cheap houses. Interestingly, the mortgage rates appear to be positive and significant during bull markets, suggesting that a decrease in the mortgage rate raises the liquid house prices more than the illiquid house prices. This result implies that easier money due to a lower mortgage rate does not stimulate upscale in house purchase.

\section{Conclusions}

We show that the illiquidity costs are significant, i.e., $0.08 \%$ per month to $0.13 \%$ per month, for bull and bear markets, respectively, thereby significantly reducing the residential property returns. The illiquidity risk appears to affect the returns of residential properties differently depending on market cycles. Our analysis of the effects of illiquidity risk on residential property returns demonstrates that illiquid properties have smaller illiquidity betas measured by covariances between returns and illiquidity costs in bull markets. We interpret this as 'Flight to Quality', which implies that households prefer high quality illiquid properties to low quality liquid properties. This is in contrast to 'Flight to Liquidity', which is welldocumented in financial markets (e.g., Longstaff, 2004; Acharya and Pedersen, 2005; Beber, Brandt, and Kavajecz, 2009; Acharya, Amihud, and Bharath, 2013). The 'Flight to Quality' phenomenon exists particularly during bull markets; thus, illiquid properties tend to show relatively higher returns compared to liquid properties. 
Overall, the results of this study suggest that households do not care about illiquidity in residential properties, i.e., FTQ exists but FTL is not significant in the housing markets. If households cared about illiquidity in residential properties, the required returns of the illiquid properties would be higher than those of liquid properties, and thus, a positive illiquidity premium or FTL would exist. However, we did not find any evidence that supports FTL. 


\section{Appendix Residential property pricing with illiquidity costs and dwelling benefits}

Household's optimization problem in the residential property investment is

$$
\begin{array}{ll}
\text { Max. } & V\left(C_{t}, C_{t+1}\right)=U\left(C_{t}\right)+\rho E_{t}\left[U\left(C_{t+1}\right)\right], \\
\text { s.t. } & C_{t}=k_{t}-w p_{t}, \\
& C_{t+1}=k_{t+1}+w\left(p_{t+1}-Q_{t+1}\right)+w p_{t} d_{t+1} .
\end{array}
$$

We obtain the first order condition for $w$ by substituting the constraints into the objective function and taking the first derivative with respect to $w$ :

$$
\frac{\partial \mathrm{V}}{\partial w}=-\mathrm{U}^{\prime}\left(C_{t}\right) p_{t}+\rho \mathrm{E}_{\mathrm{t}}\left[\mathrm{U}^{\prime}\left(C_{t+1}\right)\left(p_{t+1}-Q_{t+1}+p_{t} d_{t+1}\right)\right]=0
$$

or

$$
1=\mathrm{E}_{\mathrm{t}}\left[\rho \frac{\mathrm{U} \prime\left(C_{t+1}\right)}{\mathrm{U} \prime\left(C_{t}\right)}\left(1+r_{t+1}-q_{t+1}+d_{t+1}\right)\right]
$$

where $q_{t+1}=Q_{t+1} / p_{t}$, which represents the relative illiquidity cost to price. The Euler equation can be rearranged as follows:

$1=\mathrm{E}_{\mathrm{t}}\left[m_{\mathrm{t}+1}\right]+\mathrm{E}_{\mathrm{t}}\left[m_{\mathrm{t}+1}\right] \mathrm{E}_{\mathrm{t}}\left[r_{t+1}-q_{t+1}+d_{t+1}\right]+\operatorname{Cov}\left(m, r_{t+1}-q_{t+1}+d_{t+1}\right)$,

where $m_{\mathrm{t}+1}=\rho \frac{\mathrm{U} /\left(C_{t+1}\right)}{\mathrm{U}\left(C_{t}\right)}$ is the discount factor, the so-called pricing kernel, and the expected value of which is the reciprocal of the risk-free rate (Cochrane, 2005) is shown as

$$
\frac{1}{1+\mathrm{r}^{\mathrm{f}}}=\mathrm{E}_{\mathrm{t}}\left[m_{\mathrm{t}+1}\right]
$$

If we incorporate (A.7) into (A.6), we can express the expected return of the liquid house as follows:

$$
1+\mathrm{r}^{\mathrm{f}}=1+\mathrm{E}_{\mathrm{t}}\left[r_{t+1}+d_{t+1}-q_{t+1}\right]+\frac{\operatorname{Cov}\left(m_{\mathrm{t}+1}, r_{t+1}+d_{t+1}-q_{t+1}\right)}{\mathrm{E}_{\mathrm{t}}\left[m_{\mathrm{t}+1}\right]}
$$

or

$$
\mathrm{E}_{\mathrm{t}}\left[r_{t+1}+d_{t+1}-q_{t+1}-\mathrm{r}^{\mathrm{f}}\right]=-\frac{\operatorname{Cov}\left(m_{\mathrm{t}+1}, r_{t+1}+d_{t+1}-q_{t+1}\right)}{\mathrm{E}_{\mathrm{t}}\left[m_{\mathrm{t}+1}\right]}
$$


Following the procedure similar to the above, the return of the market portfolio can be presented as follows:

$$
\mathrm{E}_{\mathrm{t}}\left[r_{t+1}^{M}+d_{t+1}-q_{\mathrm{t}+1}^{M}-\mathrm{r}^{\mathrm{f}}\right]=-\frac{\operatorname{Cov}\left(m_{\mathrm{t}+1}, r_{t+1}^{M}+d_{t+1}-q_{\mathrm{t}+1}^{M}\right)}{\mathrm{E}_{\mathrm{t}}\left[m_{\mathrm{t}+1}\right]}
$$

where the superscript $M$ means the residential property market.

Incorporating (A.10) into (A.9) yields

$\mathrm{E}_{\mathrm{t}}\left[r_{t+1}+d_{t+1}-q_{t+1}-\mathrm{r}^{\mathrm{f}}\right]=\frac{\operatorname{Cov}\left(m_{\mathrm{t}+1}, r_{t+1}+d_{t+1}-q_{t+1}\right)}{\operatorname{Cov}\left(m_{\mathrm{t}+1}, r_{t+1}^{M}+d_{t+1}-q_{\mathrm{t}+1}^{M}\right)} \mathrm{E}_{\mathrm{t}}\left[r_{t+1}^{M}+d_{t+1}-q_{\mathrm{t}+1}^{M}-\mathrm{r}^{\mathrm{f}}\right]$.

The assumption of a representative agent in a static setting allows the consumption to be equivalent with the aggregate wealth; thus, the pricing kernel can be expressed as a function of aggregated wealth, $\frac{\mathrm{U} /\left(W_{t+1}\right)}{\mathrm{U} /\left(W_{t}\right)}$ (Brown and Gibbons, 1985; Dittmar, 2002). As illiquidity costs and dwelling benefits as well as market return compose the aggregate wealth change in our framework, the pricing kernel can be expressed as a nonlinear function of the return on the aggregate wealth by using a Taylor series expansion as follows (Harvey and Siddique, 2000; Dittmar, 2002):

$$
m_{\mathrm{t}+1}=a_{0}+a_{1} \frac{\mathrm{U} \prime \prime}{\mathrm{U} \prime}\left(r_{t+1}^{M}-q_{\mathrm{t}+1}^{M}+d_{t+1}\right)+a_{2} \frac{\mathrm{U} \prime \prime \prime}{\mathrm{U} \prime}\left(r_{t+1}^{M}-q_{\mathrm{t}+1}^{M}+d_{t+1}\right)^{2}+\cdots
$$

We assume that the pricing kernel is linear in the return on the aggregate wealth as follows (e.g., Harvey and Siddique, 2000):

$$
m_{t+1}=a_{t}+b_{t}\left(r_{t+1}^{M}-q_{t+1}^{M}+d_{t+1}\right) .
$$

Incorporating (A.13) into (A.11) yields

$$
\mathrm{E}_{\mathrm{t}}\left[r_{t+1}+d_{t+1}-q_{t+1}-\mathrm{r}^{\mathrm{f}}\right]=\frac{\operatorname{Cov}\left[r_{t+1}^{M}+d_{t+1}-q_{\mathrm{t}+1}^{M}, r_{t+1}+d_{t+1}-q_{t+1}\right]}{\operatorname{Var}\left[r_{t+1}^{M}+d_{t+1}-q_{\mathrm{t}+1}^{M}\right]} \mathrm{E}_{\mathrm{t}}\left[r_{t+1}^{M}+d_{t+1}-q_{\mathrm{t}+1}^{M}-\mathrm{r}^{\mathrm{f}}\right] .
$$

QED. 


\section{References}

Acharya, V. and L. H. Pedersen, 2005, Asset pricing with liquidity risk, Journal of Financial Economics 77:375-410.

Acharya, V., Y. Amihud, and S.T. Bharath, 2013, Liquidity risk of corporate bond returns: conditional approach, Journal of Financial Economics 110:358-386.

Aiyagari, S. R. and M. Gertler, 1991, Asset returns with transactions costs and uninsurable individual risk, Journal of Monetary Economics 27:311-331.

Amihud, Y., 2002, Illiquidity and stock returns: cross-section and time-series effects, Journal of Financial Markets 5:31-56.

Amihud, Y. and H. Mendelson, 1986, Asset pricing and the bid-ask spread, Journal of Financial Economics 17:223-249.

Ang, A. and J. Chen, 2007, CAPM over the long run: 1926-2001, Journal of Empirical Finance 14:1-40.

Anglin, P., 2003, The value and liquidity effects of a change in market conditions, University of Windsor Working Paper.

Beber, A., M.W. Brandt, and K.A. Kavajecz, 2009, Flight-to-Quality or Flight-to-Liquidity? Evidence from the Euro-Area Bond Market, Review of Financial Studies 22:925957.

Bond, S.A., S. Hwang, and G. Marcato, 2012, Commercial Real Estate Returns: An Anatomy of Smoothing in Asset and Index Returns, Real Estate Economics 40(4):637-661.

Bond, S.A., S. Hwang, Z. Lin, and K.D. Vandell, 2007, Marketing Period Risk in a Portfolio Context: Theory and Empirical Estimates from the UK Commercial Real Estate Market, Journal of Real Estate Finance and Economics 34:447-461.

Brown, D.P. and M.R. Gibbons, 1985, A Simple Econometric Approach for Utility-Based Asset Pricing Models, Journal of Finance 40:359-381.

Carrillo, P.E. and J.C. Pope, 2012, Are homes hot or cold potatoes? The distribution of marketing time in the housing market, Regional Science and Urban Economics 42:189-197.

Campbell, J.Y., 2003, Consumption-based asset pricing, In Handbook of the Economics of Finance Vol.1B:803-887, ed. G. Constantinides, R.M. Stultz, M. Harris, Elsevier.

Campbell, J.Y., S. Giglio, and P. Pathak, 2011, Forced Sales and House Prices, American Economic Review 101:2108-2131.

Case, B., H.O. Pollakowski, and S.M. Wachter, 1997, Frequency of Transaction and House Price Modeling, Journal of Real Estate Finance and Economics 14: 173-187.

Case, K.E. and R.J. Shiller, 1989, The Efficiency of the Market for Single-Family Homes, The American Economic Review 79:125-137.

Chien, Y. and H. Lustig, 2010, The Market Price of Aggregate Risk and the Wealth Distribution, Review of Financial Studies 23:1596-1650.

Cho, Y., S. Hwang, and Y. Lee, 2014, The Dynamics of Appraisal Smoothing, Real Estate Economics 42(2):497-529.

Cho, Y., S. Hwang, and S. Satchell, 2012, The Optimal Mortgage Loan Portfolio in UK Regional Residential Real Estate, Journal of Real Estate Finance and Economics 45:645-677.

Chordia, T., R. Roll, and A. Subrahmanyam, 2000, Commonality in liquidity, Journal of Financial Economics 56:3-28.

Clapp, J.M. and C. Giaccotto, 1992, Estimating Price Indices for Residential Property: A Comparison of Repeat Sales and Assessed Value Methods, Journal of the American Statistical Association 87:300-306. 
Clark, W.A.V., M.C. Deurloo, and F.M. Dieleman, 2003, Housing Careers in the United States, 1968-93: Modelling the Sequencing of Housing States, Urban Studies 40:143-160.

Cochrane, J.H. 2005, Asset Pricing, Princeton University Press.

Collett, D., C. Lizieri, and C. Ward, 2003, Timing and the Holding Periods of Institutional Real Estate, Real Estate Economics 31(2):205-222.

Constantinides, 1986, Capital market equilibrium with transaction costs, Journal of Political Economy 94:842-862.

Davis, M.A., A. Lehnert, and R.F. Martin, 2008, The Rent-Price Ratio for the Aggregate Stock of Owner-Occupied Housing, Review of Income and Wealth 54:279-284.

Davis, M.A. and M.G. Palumbo, 2007, The Price of Residential Land in Large US Cities, Journal of Urban Economics 63: 352-384; data located at Land and Property Values in the U.S., Lincoln Institute of Land Policy.

Dittmar, R.F., 2002, Nonlinear Pricing Kernels, Kurtosis Preference, and Evidence from the Cross Section of Equity Returns, Journal of Finance 57:369-403.

Duffie, D., N. Garleanu, and L.H. Pedersen, 2002, Securities lending, shorting, and pricing, Journal of Financial Economics 66:307-339.

Fama, E.F. and K.R. French, 1992, The Cross-Section of Expected Stock Returns, Journal of Finance 47:427-465.

Fama, E.F. and K.R. French, 2001, Disappearing dividends: Changing firm characteristics or lower propensity to pay, Journal of Financial Economics 60:3-43.

Ferson, W. and C. Harvey, 1993, The risk and predictability of international equity returns, Review of Financial Studies 6:527-566.

Fisher, J., D. Gatzlaff, D. Geltner, and D. Haurin, 2003, Controlling for the Impact of Variable Liquidity in Commercial Real Estate Price Indices, Real Estate Economics 31:269-303.

Fisher, J., D. Geltner, and H. Pollakowski, 2007, A Quarterly Transaction-based Index of Institutional Real Estate Investment Performance and Movements in Supply and Demand, Journal of Real Estate Finance and Economics 34:5-33.

Flavin, M. and S. Nakagawa, 2008, A Model of Housing in the Presence of Adjustment Costs: A Structural Interpretation of Habit Persistence, American Economic Review 1: 474495.

Glower, M., D.R. Haurin, and P.H. Hendershott, 1998, Selling Time and Selling Price: The Influence of Seller Motivation, Real Estate Economics 24:719-740.

Goswami, G., and S. Tan, 2012, Pricing the US residential asset through the rent flow: A cross-sectional study, Journal of Banking and Finance 36(10):2742-2756.

Grossman, S.J. and M.H. Miller, 1988, Liquidity and market structure, Journal of Finance 43:617-633.

Harvey, C.R. and A. Siddique, 2000, Conditional Skewness in Asset Pricing Tests, Journal of Finance 55:1263-1295

Heaton, J. and D.J. Lucas, 1996, Evaluating the effects of incomplete markets on risk sharing and asset pricing, Journal of Political Economy 104:443-487.

Hendel, I., A. Nevo, and F. Ortalo-Magne, 2009, The Relative Performance of Real Estate Marketing Platforms: MLS versus FSBOMadison.com, American Economic Review 99:1878-1898.

Hooker, M.A. and M. Kohn, 1994, An Empirical Measure of Asset Liquidity, Dartmouth College Department of Economics Working Paper.

Hwang, S. and C. Lu, 2008, Cross-Sectional Stock Returns in the UK Market: The Role of Liquidity Risk, Working Paper, available at SSRN:http://ssrn.com/abstract=969809 
Jud, G.D., T.G. Seaks, and D.T. Winkler, 1996, Time on the Market: The Impact of Residential Brokerage, Journal of Real Estate Research 12:447-458.

Kawaguchi, Y., J. Sa-Aadu, and J.D. Shilling, 2007, Do Changes in Illiquidity Affect Investors' Expectations? An Analysis of the Commercial Property Returns, Working Paper.

Knight, J., 2002, Listing Price, Time on the Market, and Ultimate Selling Price: Causes and Effects of Listing Price Changes, Real Estate Economics 30:213-237.

Krainer, J., 2001, A theory of real estate liquidity in residential real estate markets, Journal of Urban Economics 49: 32-53.

Krainer, J., M.M. Spiegel, and N. Yamori, 2010, Asset Price Persistence and Real Estate Market Illiquidity: Evidence from Japanese Land Values, Real Estate Economics 38:171-196.

Kyle, A.S., 1985, Continuous Auctions and Insider Trading, Econometrica 53:1315-1336.

Ngai, R. and S. Tenreyro, 2014, Hot and Cold Seasons in the Housing Market, American Economic Review 104(12):3991-4026.

Lin, Z. and K.D. Vandell, 2007, Illiquidity and pricing biases in the real estate market, Real Estate Economics 35:291-330.

Ling, D. and A. Naranjo, 1997, Economic risk factors and commercial real estate returns, Journal of Real Estate Finance and Economics 14: 283-307.

Lippman, S. and J. McCall, 1986, An operational measure of liquidity, American Economic Review 76:43-55.

Longstaff, F.A., 2004, The Flight-to-Liquidity Premium in U.S. Treasury Bond Prices, Journal of Business 77:511-526.

Mehra, R., 2012, Consumption-Based Asset Pricing Models, Annual Review of Financial Economics 4:385-409.

Olkarinen, E., and H. Kahra, 2002, A Consumption based explanation of equity and housing property returns, Pacific RIM real estate society conference 2002.

Pastor, L. and R. Stambaugh, 2003, Liquidity risk and expected stock returns, Journal of Political Economy 111: 642-685.

Petkova, R. and L. Zhang, 2005, Is value riskier than growth?, Journal of Financial Economics 78:187-202.

Piazzesi, M., M. Schneider, and S. Tuzel, 2007, Housing, Consumption, and Asset Pricing, Journal of Financial Economics 83:531-569.

Rouwenhorst, K.G., 1999, Local return factors and turnover in emerging stock markets, Journal of Finance 54:1439-1464.

Salant, S.W., 1991, For Sale by Owner: When to Use a Broker and How to Price the House, Journal of Real Estate Finance and Economics 4:157-173.

Stoll, H.R., 1978, The Supply of Dealer Services in Securities Markets, Journal of Finance 4:1133-1151. 


\section{Table 1 Properties of residential property returns}

This table shows the basic properties of monthly S\&P/Case-Shiller Home Price Index returns by each of the Metropolitan Statistical Areas. The returns are classified by the market conditions using the historic house price peak in May 2006. The residential properties are divided into liquid and illiquid properties according to the price levels. Sharpe ratios are also on a monthly basis and are calculated separately by market conditions and illiquidity types of properties. IML, the difference between illiquid and liquid property returns, is negatively and positively significant in each sub-period denoted by bull and bear markets, respectively.

\section{A. Entire Period (from February 1993 to August 2012)}

Liquid property returns

\begin{tabular}{|c|c|c|c|c|c|}
\hline & $\begin{array}{l}\text { Mean } \\
\text { (A) }\end{array}$ & $\begin{array}{l}\text { Std. } \\
\text { Dev. } \\
\text { (B) }\end{array}$ & $\begin{array}{c}\text { Skew- } \\
\text { ness }\end{array}$ & $\begin{array}{c}\text { Kurt- } \\
\text { osis }\end{array}$ & $\begin{array}{c}\text { Sharpe } \\
\text { ratio } \\
=(\mathrm{A}) /(\mathrm{B})\end{array}$ \\
\hline Atlanta & $-0.06 \%$ & $2.08 \%$ & -2.18 & 10.64 & $-2.79 \%$ \\
\hline Boston & $0.44 \%$ & $1.43 \%$ & -0.30 & 0.83 & $30.61 \%$ \\
\hline Chicago & $0.12 \%$ & $1.72 \%$ & -1.52 & 7.37 & $6.72 \%$ \\
\hline Denver & $0.46 \%$ & $1.19 \%$ & -0.54 & 1.29 & $38.97 \%$ \\
\hline Las Vegas & $0.05 \%$ & $1.87 \%$ & -1.17 & 4.09 & $2.45 \%$ \\
\hline Los Angeles & $0.26 \%$ & $1.63 \%$ & -1.08 & 1.91 & $16.16 \%$ \\
\hline Miami & $0.25 \%$ & $1.82 \%$ & -1.86 & 4.90 & $13.59 \%$ \\
\hline Minneapolis & $0.29 \%$ & $2.21 \%$ & -1.26 & 5.68 & $13.32 \%$ \\
\hline New York & $0.35 \%$ & $1.08 \%$ & -0.88 & 1.36 & $32.42 \%$ \\
\hline Phoenix & $0.22 \%$ & $2.39 \%$ & -2.18 & 8.40 & $9.32 \%$ \\
\hline Portland & $0.44 \%$ & $1.19 \%$ & -1.07 & 1.89 & $37.17 \%$ \\
\hline San Diego & $0.32 \%$ & $1.51 \%$ & -0.71 & 0.68 & $21.30 \%$ \\
\hline San Francisco & $0.23 \%$ & $1.76 \%$ & -1.26 & 2.00 & $13.23 \%$ \\
\hline Seattle & $0.29 \%$ & $1.13 \%$ & -1.15 & 2.10 & $25.68 \%$ \\
\hline Tampa & $0.22 \%$ & $1.73 \%$ & -1.06 & 2.64 & $12.83 \%$ \\
\hline Washington DC & $0.31 \%$ & $1.57 \%$ & -0.87 & 2.30 & $19.76 \%$ \\
\hline Average & $0.26 \%$ & $1.64 \%$ & -1.19 & 3.63 & $18.17 \%$ \\
\hline
\end{tabular}

Illiquid property returns

\begin{tabular}{ccccc}
\hline $\begin{array}{c}\text { Mean } \\
(\mathrm{A})\end{array}$ & $\begin{array}{c}\text { Std. } \\
\text { Dev. } \\
(\mathrm{B})\end{array}$ & $\begin{array}{c}\text { Skew- } \\
\text { ness }\end{array}$ & $\begin{array}{c}\text { Kurt- } \\
\text { osis }\end{array}$ & $\begin{array}{c}\text { Sharpe } \\
\text { ratio } \\
=(\mathrm{A}) /(\mathrm{B})\end{array}$ \\
\hline $0.16 \%$ & $0.94 \%$ & -0.96 & 2.71 & $17.34 \%$ \\
$0.37 \%$ & $0.94 \%$ & -0.12 & -0.11 & $39.97 \%$ \\
$0.21 \%$ & $1.12 \%$ & -0.69 & 3.06 & $18.50 \%$ \\
$0.34 \%$ & $0.81 \%$ & -0.55 & 0.76 & $41.81 \%$ \\
$0.10 \%$ & $1.45 \%$ & 0.03 & 4.21 & $6.70 \%$ \\
$0.33 \%$ & $1.18 \%$ & -0.28 & 0.95 & $27.92 \%$ \\
$0.28 \%$ & $1.21 \%$ & -0.94 & 1.36 & $23.02 \%$ \\
$0.24 \%$ & $1.25 \%$ & -0.66 & 3.56 & $19.60 \%$ \\
$0.33 \%$ & $0.83 \%$ & -0.40 & 0.29 & $39.74 \%$ \\
$0.29 \%$ & $1.30 \%$ & -0.69 & 3.13 & $22.07 \%$ \\
$0.29 \%$ & $1.01 \%$ & -0.61 & 1.26 & $29.04 \%$ \\
$0.31 \%$ & $1.20 \%$ & -0.16 & 0.76 & $25.74 \%$ \\
$0.36 \%$ & $1.39 \%$ & -0.16 & 1.21 & $26.19 \%$ \\
$0.33 \%$ & $1.01 \%$ & -0.95 & 2.58 & $32.51 \%$ \\
$0.22 \%$ & $1.16 \%$ & -0.83 & 1.97 & $18.80 \%$ \\
$0.34 \%$ & $0.99 \%$ & 0.02 & 0.40 & $34.38 \%$ \\
\hline $0.28 \%$ & $1.11 \%$ & -0.50 & 1.76 & $26.46 \%$ \\
\hline & & & &
\end{tabular}

IML

(Illiquid Minus Liquid returns)

\begin{tabular}{cc}
\hline Mean & $\begin{array}{c}\text { Std. } \\
\text { Error }\end{array}$ \\
\hline $0.22 \%$ & $0.11 \%$ \\
$-0.06 \%$ & $0.07 \%$ \\
$0.09 \%$ & $0.08 \%$ \\
$-0.12 \%$ & $0.05 \%$ \\
$0.05 \%$ & $0.07 \%$ \\
$0.07 \%$ & $0.06 \%$ \\
$0.03 \%$ & $0.08 \%$ \\
$-0.05 \%$ & $0.10 \%$ \\
$-0.02 \%$ & $0.05 \%$ \\
$0.06 \%$ & $0.10 \%$ \\
$-0.15 \%$ & $0.06 \%$ \\
$-0.01 \%$ & $0.06 \%$ \\
$0.13 \%$ & $0.09 \%$ \\
$0.04 \%$ & $0.06 \%$ \\
$0.00 \%$ & $0.09 \%$ \\
$0.03 \%$ & $0.08 \%$ \\
\hline $0.02 \%$ & $0.08 \%$ \\
\hline
\end{tabular}




\section{B. Bull Markets (from February 1993 to May 2006)}

\begin{tabular}{|c|c|c|c|c|c|c|c|c|c|c|c|c|}
\hline & \multicolumn{5}{|c|}{ Liquid property returns } & \multicolumn{5}{|c|}{ Illiquid property returns } & \multicolumn{2}{|c|}{$\begin{array}{l}\text { IML } \\
\text { (Illiquid Minus Liquid } \\
\text { returns) }\end{array}$} \\
\hline & $\begin{array}{c}\text { Mean } \\
\text { (A) }\end{array}$ & $\begin{array}{l}\text { Std. } \\
\text { Dev. } \\
\text { (B) }\end{array}$ & $\begin{array}{c}\text { Skew- } \\
\text { ness }\end{array}$ & $\begin{array}{l}\text { Kurt- } \\
\text { osis }\end{array}$ & $\begin{array}{l}\text { Sharpe } \\
\text { ratio } \\
=(\mathrm{A}) /(\mathrm{B})\end{array}$ & $\begin{array}{l}\text { Mean } \\
\text { (A) }\end{array}$ & $\begin{array}{l}\text { Std. } \\
\text { Dev. } \\
\text { (B) }\end{array}$ & $\begin{array}{c}\text { Skew- } \\
\text { ness }\end{array}$ & $\begin{array}{l}\text { Kurt- } \\
\text { osis }\end{array}$ & $\begin{array}{l}\text { Sharpe } \\
\text { ratio } \\
=(\mathrm{A}) /(\mathrm{B})\end{array}$ & Mean & $\begin{array}{l}\text { Std. } \\
\text { Error }\end{array}$ \\
\hline Atlanta & $0.45 \%$ & $0.37 \%$ & 0.35 & 1.21 & $120.64 \%$ & $0.38 \%$ & $0.40 \%$ & 0.35 & 0.32 & $94.80 \%$ & $-0.07 \%$ & $0.04 \%$ \\
\hline Boston & $0.79 \%$ & $0.93 \%$ & -0.36 & 0.78 & $85.16 \%$ & $0.59 \%$ & $0.79 \%$ & 0.12 & 0.02 & $73.61 \%$ & $-0.21 \%$ & $0.06 \%$ \\
\hline Chicago & $0.58 \%$ & $0.67 \%$ & -0.20 & 1.86 & $86.77 \%$ & $0.47 \%$ & $0.55 \%$ & 0.36 & 0.24 & $85.17 \%$ & $-0.11 \%$ & $0.06 \%$ \\
\hline Denver & $0.71 \%$ & $0.67 \%$ & 0.30 & -0.02 & $106.08 \%$ & $0.52 \%$ & $0.56 \%$ & -0.12 & 0.09 & $93.53 \%$ & $-0.19 \%$ & $0.04 \%$ \\
\hline Las Vegas & $0.74 \%$ & $1.08 \%$ & 2.17 & 7.33 & $68.59 \%$ & $0.64 \%$ & $1.10 \%$ & 2.46 & 8.16 & $57.62 \%$ & $-0.10 \%$ & $0.06 \%$ \\
\hline Los Angeles & $0.81 \%$ & $1.08 \%$ & 0.05 & -0.43 & $74.50 \%$ & $0.68 \%$ & $0.98 \%$ & 0.33 & 0.39 & $69.44 \%$ & $-0.12 \%$ & $0.05 \%$ \\
\hline Miami & $0.94 \%$ & $0.86 \%$ & 0.46 & -0.15 & $109.08 \%$ & $0.72 \%$ & $0.74 \%$ & 0.61 & 0.24 & $97.17 \%$ & $-0.21 \%$ & $0.05 \%$ \\
\hline Minneapolis & $0.70 \%$ & $0.74 \%$ & 0.22 & 0.03 & $95.51 \%$ & $0.52 \%$ & $0.60 \%$ & -0.12 & 1.04 & $86.71 \%$ & $-0.19 \%$ & $0.05 \%$ \\
\hline New York & $0.76 \%$ & $0.71 \%$ & -0.17 & -0.45 & $105.81 \%$ & $0.60 \%$ & $0.61 \%$ & 0.38 & -0.16 & $98.34 \%$ & $-0.16 \%$ & $0.05 \%$ \\
\hline Phoenix & $0.83 \%$ & $0.96 \%$ & 2.45 & 7.79 & $86.79 \%$ & $0.76 \%$ & $0.82 \%$ & 2.51 & 6.59 & $93.08 \%$ & $-0.07 \%$ & $0.04 \%$ \\
\hline Portland & $0.80 \%$ & $0.76 \%$ & 0.05 & -0.18 & $106.14 \%$ & $0.56 \%$ & $0.69 \%$ & 0.70 & 0.84 & $81.10 \%$ & $-0.24 \%$ & $0.06 \%$ \\
\hline San Diego & $0.83 \%$ & $1.06 \%$ & 0.21 & -0.21 & $78.95 \%$ & $0.68 \%$ & $1.00 \%$ & 0.38 & 0.64 & $68.05 \%$ & $-0.15 \%$ & $0.06 \%$ \\
\hline San Francisco & $0.84 \%$ & $1.01 \%$ & 0.16 & -0.70 & $83.51 \%$ & $0.67 \%$ & $1.15 \%$ & 0.60 & 0.80 & $57.83 \%$ & $-0.17 \%$ & $0.07 \%$ \\
\hline Seattle & $0.67 \%$ & $0.68 \%$ & 0.13 & 0.17 & $97.75 \%$ & $0.58 \%$ & $0.74 \%$ & 0.04 & -0.39 & $77.89 \%$ & $-0.09 \%$ & $0.06 \%$ \\
\hline Tampa & $0.88 \%$ & $1.05 \%$ & 0.91 & 2.03 & $83.35 \%$ & $0.61 \%$ & $0.78 \%$ & 0.60 & 0.06 & $78.43 \%$ & $-0.26 \%$ & $0.08 \%$ \\
\hline Washington DC & $0.73 \%$ & $0.99 \%$ & 0.76 & 1.14 & $73.62 \%$ & $0.60 \%$ & $0.81 \%$ & 0.76 & 0.38 & $73.46 \%$ & $-0.13 \%$ & $0.05 \%$ \\
\hline Average & $0.75 \%$ & $0.85 \%$ & 0.47 & 1.26 & $91.39 \%$ & $0.60 \%$ & $0.77 \%$ & 0.62 & 1.20 & $80.39 \%$ & $-0.16 \%$ & $0.06 \%$ \\
\hline
\end{tabular}




\section{Bear Markets (from June 2006 to August 2012)}

\begin{tabular}{|c|c|c|c|c|c|c|c|c|c|c|c|c|}
\hline & \multicolumn{5}{|c|}{ Liquid property returns } & \multicolumn{5}{|c|}{ Illiquid property returns } & \multicolumn{2}{|c|}{$\begin{array}{l}\text { IML } \\
\text { (Illiquid Minus Liquid } \\
\text { returns) }\end{array}$} \\
\hline & $\begin{array}{l}\text { Mean } \\
\text { (A) }\end{array}$ & $\begin{array}{l}\text { Std. } \\
\text { Dev. } \\
\text { (B) }\end{array}$ & $\begin{array}{c}\text { Skew- } \\
\text { ness }\end{array}$ & $\begin{array}{l}\text { Kurt- } \\
\text { osis }\end{array}$ & $\begin{array}{l}\text { Sharpe } \\
\text { ratio } \\
=(\mathrm{A}) /(\mathrm{B})\end{array}$ & $\begin{array}{l}\text { Mean } \\
\text { (A) }\end{array}$ & $\begin{array}{l}\text { Std. } \\
\text { Dev. } \\
\text { (B) }\end{array}$ & $\begin{array}{c}\text { Skew- } \\
\text { ness }\end{array}$ & $\begin{array}{l}\text { Kurt- } \\
\text { osis }\end{array}$ & $\begin{array}{l}\text { Sharpe } \\
\text { ratio } \\
=(\mathrm{A}) /(\mathrm{B})\end{array}$ & Mean & $\begin{array}{l}\text { Std. } \\
\text { Error }\end{array}$ \\
\hline Atlanta & $-1.13 \%$ & $3.42 \%$ & -0.61 & 1.70 & $-33.21 \%$ & $-0.30 \%$ & $1.47 \%$ & 0.08 & -0.46 & $-20.30 \%$ & $0.84 \%$ & $0.32 \%$ \\
\hline Boston & $-0.33 \%$ & $1.93 \%$ & 0.68 & 0.35 & $-16.87 \%$ & $-0.07 \%$ & $1.06 \%$ & 0.26 & -0.45 & $-6.98 \%$ & $0.25 \%$ & $0.18 \%$ \\
\hline Chicago & $-0.87 \%$ & $2.64 \%$ & -0.23 & 1.81 & $-33.10 \%$ & $-0.34 \%$ & $1.70 \%$ & 0.25 & 0.28 & $-20.33 \%$ & $0.53 \%$ & $0.20 \%$ \\
\hline Denver & $-0.06 \%$ & $1.76 \%$ & 0.24 & -0.60 & $-3.65 \%$ & $-0.05 \%$ & $1.09 \%$ & 0.15 & -0.43 & $-4.16 \%$ & $0.02 \%$ & $0.14 \%$ \\
\hline Las Vegas & $-1.43 \%$ & $2.31 \%$ & -0.74 & 0.32 & $-62.02 \%$ & $-1.05 \%$ & $1.45 \%$ & -0.86 & 0.65 & $-72.65 \%$ & $0.38 \%$ & $0.19 \%$ \\
\hline Los Angeles & $-0.90 \%$ & $1.96 \%$ & -0.57 & -0.03 & $-45.75 \%$ & $-0.42 \%$ & $1.22 \%$ & -0.35 & 0.53 & $-34.61 \%$ & $0.47 \%$ & $0.16 \%$ \\
\hline Miami & $-1.22 \%$ & $2.38 \%$ & -0.88 & 0.65 & $-51.35 \%$ & $-0.67 \%$ & $1.45 \%$ & -0.22 & -0.71 & $-45.98 \%$ & $0.55 \%$ & $0.20 \%$ \\
\hline Minneapolis & $-0.58 \%$ & $3.62 \%$ & -0.20 & 0.30 & $-16.10 \%$ & $-0.34 \%$ & $1.91 \%$ & 0.29 & 0.53 & $-17.77 \%$ & $0.24 \%$ & $0.29 \%$ \\
\hline New York & $-0.52 \%$ & $1.21 \%$ & -0.21 & 0.74 & $-43.03 \%$ & $-0.24 \%$ & $0.95 \%$ & 0.17 & -0.50 & $-25.71 \%$ & $0.28 \%$ & $0.11 \%$ \\
\hline Phoenix & $-1.08 \%$ & $3.68 \%$ & -0.96 & 1.20 & $-29.46 \%$ & $-0.73 \%$ & $1.54 \%$ & -0.46 & -0.17 & $-47.03 \%$ & $0.36 \%$ & $0.28 \%$ \\
\hline Portland & $-0.33 \%$ & $1.53 \%$ & -0.34 & -0.22 & $-21.30 \%$ & $-0.28 \%$ & $1.31 \%$ & -0.10 & -0.53 & $-21.12 \%$ & $0.05 \%$ & $0.11 \%$ \\
\hline San Diego & $-0.77 \%$ & $1.73 \%$ & -0.18 & -0.75 & $-44.67 \%$ & $-0.48 \%$ & $1.21 \%$ & -0.09 & 0.48 & $-39.84 \%$ & $0.29 \%$ & $0.15 \%$ \\
\hline San Francisco & $-1.06 \%$ & $2.28 \%$ & -0.37 & -0.57 & $-46.64 \%$ & $-0.28 \%$ & $1.63 \%$ & -0.13 & 0.41 & $-17.22 \%$ & $0.78 \%$ & $0.21 \%$ \\
\hline Seattle & $-0.51 \%$ & $1.45 \%$ & -0.34 & -0.21 & $-35.04 \%$ & $-0.20 \%$ & $1.28 \%$ & -0.62 & 1.07 & $-15.48 \%$ & $0.31 \%$ & $0.12 \%$ \\
\hline Tampa & $-1.17 \%$ & $2.05 \%$ & -0.51 & 0.24 & $-57.20 \%$ & $-0.63 \%$ & $1.38 \%$ & -0.38 & 0.37 & $-45.33 \%$ & $0.55 \%$ & $0.22 \%$ \\
\hline Washington DC & $-0.59 \%$ & $2.11 \%$ & -0.24 & -0.06 & $-27.87 \%$ & $-0.21 \%$ & $1.10 \%$ & 0.18 & -0.38 & $-18.91 \%$ & $0.38 \%$ & $0.20 \%$ \\
\hline Average & $-0.79 \%$ & $2.25 \%$ & -0.34 & 0.30 & $-35.45 \%$ & $-0.39 \%$ & $1.36 \%$ & -0.11 & 0.04 & $-28.34 \%$ & $0.39 \%$ & $0.19 \%$ \\
\hline
\end{tabular}




\section{Table 2 Illiquidity cost estimation}

This table summarizes the estimated illiquidity costs during bull and bear markets, and the maximum illiquidity costs for whole properties as well as liquid and illiquid properties, respectively. The first panel shows the estimated marketing periods of illiquid and liquid properties in bull and bear markets, respectively. Panels B, C and $\mathrm{D}$ show the estimated illiquidity costs, including the realtor commission and the costs of immediacy, i.e., the marketing periods times the cost of immediacy per month. The monthly illiquidity costs are obtained by amortizing the gross illiquidity costs over holding periods, which are set to 138 and 160 months for liquid and illiquid properties, respectively.

\section{A. Estimated marketing periods (months)}

\begin{tabular}{cccc} 
& $\begin{array}{c}\text { Bull } \\
\text { markets }\end{array}$ & $\begin{array}{c}\text { Bear } \\
\text { markets }\end{array}$ & Maximum \\
\hline Illiquid properties & 3.9 & 10.9 & 22.9 \\
Liquid properties & 1.6 & 2.7 & 4.3 \\
Whole properties & 2.6 & 6.4 & 22.9 \\
\hline
\end{tabular}

\section{B. Whole residential properties}

\begin{tabular}{ccccccccc} 
& $\begin{array}{c}\text { The estimated } \\
\text { illiquidity costs } \\
\text { during bull markets }\end{array}$ & $\begin{array}{c}\text { The estimated } \\
\text { illiquidity costs } \\
\text { during bear markets }\end{array}$ & $\begin{array}{c}\text { Average over } \\
\text { whole periods }\end{array}$ & \multicolumn{2}{c}{$\begin{array}{c}\text { The maximum } \\
\text { illiquidity costs* }\end{array}$} \\
\cline { 2 - 9 } & $\begin{array}{c}\text { Gross } \\
\text { costs }\end{array}$ & $\begin{array}{c}\text { Monthly } \\
\text { costs }\end{array}$ & $\begin{array}{c}\text { Gross } \\
\text { costs }\end{array}$ & $\begin{array}{c}\text { Monthly } \\
\text { costs }\end{array}$ & $\begin{array}{c}\text { Gross } \\
\text { costs }\end{array}$ & $\begin{array}{c}\text { Monthly } \\
\text { costs }\end{array}$ & $\begin{array}{c}\text { Gross } \\
\text { costs }\end{array}$ & $\begin{array}{c}\text { Monthly } \\
\text { costs }\end{array}$ \\
\hline $\begin{array}{c}\text { Realtor } \\
\begin{array}{c}\text { Commission } \\
\text { Cost of Immediacy }\end{array}\end{array}$ & $6.00 \%$ & $0.04 \%$ & $6.00 \%$ & $0.04 \%$ & $6.00 \%$ & $0.04 \%$ & $6.00 \%$ & $0.04 \%$ \\
\hline The estimated costs & $11.60 \%$ & $0.04 \%$ & $13.78 \%$ & $0.09 \%$ & $6.91 \%$ & $0.05 \%$ & $49.32 \%$ & $0.25 \%$ \\
\hline
\end{tabular}

\section{Liquid residential properties}

\begin{tabular}{ccccccccc} 
& $\begin{array}{c}\text { The estimated } \\
\text { illiquidity costs } \\
\text { during bull markets }\end{array}$ & \multicolumn{2}{c}{$\begin{array}{c}\text { The estimated } \\
\text { illiquidity costs } \\
\text { during bear markets }\end{array}$} & $\begin{array}{c}\text { Average over } \\
\text { whole periods }\end{array}$ & \multicolumn{2}{c}{$\begin{array}{c}\text { The maximum } \\
\text { illiquidity costs* }\end{array}$} \\
\cline { 2 - 9 } & $\begin{array}{c}\text { Gross } \\
\text { costs }\end{array}$ & $\begin{array}{c}\text { Monthly } \\
\text { costs }\end{array}$ & $\begin{array}{c}\text { Gross } \\
\text { costs }\end{array}$ & $\begin{array}{c}\text { Monthly } \\
\text { costs }\end{array}$ & $\begin{array}{c}\text { Gross } \\
\text { costs }\end{array}$ & $\begin{array}{c}\text { Monthly } \\
\text { costs }\end{array}$ & $\begin{array}{c}\text { Gross } \\
\text { costs }\end{array}$ & $\begin{array}{c}\text { Monthly } \\
\text { costs }\end{array}$ \\
\hline $\begin{array}{c}\text { Realtor } \\
\text { Commission }\end{array}$ & $6.00 \%$ & $0.04 \%$ & $6.00 \%$ & $0.04 \%$ & $6.00 \%$ & $0.04 \%$ & $6.00 \%$ & $0.04 \%$ \\
Cost of Immediacy & $3.45 \%$ & $0.02 \%$ & $5.82 \%$ & $0.04 \%$ & $3.83 \%$ & $0.02 \%$ & $9.35 \%$ & $0.06 \%$ \\
\hline The estimated costs & $9.45 \%$ & $0.06 \%$ & $11.82 \%$ & $0.08 \%$ & $9.83 \%$ & $0.06 \%$ & $15.35 \%$ & $0.10 \%$ \\
\hline
\end{tabular}

\section{Illiquid residential properties}

\begin{tabular}{ccccccccc} 
& $\begin{array}{c}\text { The estimated } \\
\text { illiquidity costs } \\
\text { during bull markets }\end{array}$ & $\begin{array}{c}\text { The estimated } \\
\text { illiquidity costs } \\
\text { during bear markets }\end{array}$ & \multicolumn{2}{c}{$\begin{array}{c}\text { Average over } \\
\text { whole periods }\end{array}$} & \multicolumn{2}{c}{$\begin{array}{c}\text { The maximum } \\
\text { illiquidity costs* }\end{array}$} \\
\cline { 2 - 9 } & $\begin{array}{c}\text { Gross } \\
\text { costs }\end{array}$ & $\begin{array}{c}\text { Monthly } \\
\text { costs }\end{array}$ & $\begin{array}{c}\text { Gross } \\
\text { costs }\end{array}$ & $\begin{array}{c}\text { Monthly } \\
\text { costs }\end{array}$ & $\begin{array}{c}\text { Gross } \\
\text { costs }\end{array}$ & $\begin{array}{c}\text { Monthly } \\
\text { costs }\end{array}$ & $\begin{array}{c}\text { Gross } \\
\text { costs }\end{array}$ & $\begin{array}{c}\text { Monthly } \\
\text { costs }\end{array}$ \\
\hline $\begin{array}{c}\text { Realtor } \\
\begin{array}{c}\text { Commission } \\
\text { Cost of Immediacy }\end{array}\end{array}$ & $6.00 \%$ & $0.04 \%$ & $6.00 \%$ & $0.04 \%$ & $6.00 \%$ & $0.04 \%$ & $6.00 \%$ & $0.04 \%$ \\
\hline The estimated costs & $14.40 \%$ & $0.05 \%$ & $23.48 \%$ & $0.13 \%$ & $10.81 \%$ & $0.06 \%$ & $49.32 \%$ & $0.25 \%$ \\
\hline
\end{tabular}




\section{Table 3 Properties of the Amihud measure and the normalized illiquidity costs}

This table shows the basic properties of the Amihud (2002) illiquidity measure as well as the normalized measures. The illiquidity costs normalized by the first and third methods have similar means to that in Table 2, i.e., $0.08 \%$ per month. The second method is designed to generate illiquidity costs with a lower mean with higher volatility, whereas the third method is to generate illiquidity costs with a lower volatility. As expected, the measure and the illiquidity costs have similar statistical properties and relatively larger means and volatilities during bear markets.

\begin{tabular}{|c|c|c|c|c|c|c|c|c|c|c|c|c|c|c|c|c|c|c|}
\hline & \multicolumn{6}{|c|}{ A. Entire Period } & \multicolumn{6}{|c|}{ B. Bull Markets } & \multicolumn{6}{|c|}{ C. Bear Markets } \\
\hline & Min. & Max. & Mean & $\begin{array}{l}\text { Std. } \\
\text { Dev. }\end{array}$ & $\begin{array}{c}\text { Skew- } \\
\text { ness }\end{array}$ & $\begin{array}{c}\text { Kurt- } \\
\text { osis }\end{array}$ & Min. & Max. & Mean & $\begin{array}{l}\text { Std. } \\
\text { Dev. }\end{array}$ & $\begin{array}{c}\text { Skew- } \\
\text { ness }\end{array}$ & $\begin{array}{c}\text { Kurt- } \\
\text { osis }\end{array}$ & Min. & Max. & Mean & $\begin{array}{l}\text { Std. } \\
\text { Dev. }\end{array}$ & $\begin{array}{c}\text { Skew- } \\
\text { ness }\end{array}$ & $\begin{array}{c}\text { Kurt- } \\
\text { osis }\end{array}$ \\
\hline$A$ & $0.080 \%$ & $2.140 \%$ & $0.350 \%$ & $0.320 \%$ & 2.96 & 10.21 & $0.080 \%$ & $0.591 \%$ & $0.236 \%$ & $0.099 \%$ & 1.11 & 1.13 & $0.081 \%$ & $2.145 \%$ & $0.603 \%$ & $0.460 \%$ & 1.48 & 1.89 \\
\hline$q^{H}$ & $0.000 \%$ & $0.290 \%$ & $0.106 \%$ & $0.088 \%$ & 0.95 & -0.34 & $0.000 \%$ & $0.251 \%$ & $0.070 \%$ & $0.050 \%$ & 1.13 & 1.15 & $0.000 \%$ & $0.290 \%$ & $0.183 \%$ & $0.101 \%$ & -0.41 & -1.36 \\
\hline$q^{L}$ & $0.005 \%$ & $0.100 \%$ & $0.054 \%$ & $0.031 \%$ & 0.38 & -1.27 & $0.005 \%$ & $0.100 \%$ & $0.043 \%$ & $0.023 \%$ & 0.83 & 0.04 & $0.005 \%$ & $0.100 \%$ & $0.078 \%$ & $0.031 \%$ & -0.96 & -0.70 \\
\hline$q^{M}$ & $0.009 \%$ & $0.290 \%$ & $0.084 \%$ & $0.069 \%$ & 1.68 & 2.27 & $0.009 \%$ & $0.162 \%$ & $0.056 \%$ & $0.030 \%$ & 1.11 & 1.13 & $0.009 \%$ & $0.290 \%$ & $0.143 \%$ & $0.088 \%$ & 0.36 & -1.02 \\
\hline$q^{H^{\prime}}$ & $0.000 \%$ & $0.290 \%$ & $0.099 \%$ & $0.092 \%$ & 0.96 & -0.38 & $0.000 \%$ & $0.255 \%$ & $0.061 \%$ & $0.053 \%$ & 1.24 & 1.29 & $0.000 \%$ & $0.290 \%$ & $0.180 \%$ & $0.106 \%$ & -0.41 & -1.42 \\
\hline$q^{L^{\prime}}$ & $0.000 \%$ & $0.100 \%$ & $0.041 \%$ & $0.040 \%$ & 0.49 & -1.42 & $0.000 \%$ & $0.100 \%$ & $0.027 \%$ & $0.031 \%$ & 1.13 & 0.13 & $0.000 \%$ & $0.100 \%$ & $0.072 \%$ & $0.040 \%$ & -0.87 & -1.08 \\
\hline$q^{M^{\prime}}$ & $0.000 \%$ & $0.290 \%$ & $0.074 \%$ & $0.081 \%$ & 1.42 & 1.11 & $0.000 \%$ & $0.181 \%$ & $0.040 \%$ & $0.038 \%$ & 1.29 & 1.39 & $0.000 \%$ & $0.290 \%$ & $0.146 \%$ & $0.100 \%$ & 0.09 & -1.32 \\
\hline$q^{H^{\prime \prime}}$ & $0.037 \%$ & $0.290 \%$ & $0.104 \%$ & $0.062 \%$ & 1.68 & 2.28 & $0.037 \%$ & $0.174 \%$ & $0.079 \%$ & $0.027 \%$ & 1.11 & 1.13 & $0.037 \%$ & $0.290 \%$ & $0.157 \%$ & $0.080 \%$ & 0.37 & -1.02 \\
\hline$q^{L^{\prime \prime}}$ & $0.019 \%$ & $0.100 \%$ & $0.055 \%$ & $0.025 \%$ & 0.67 & -0.90 & $0.019 \%$ & $0.100 \%$ & $0.045 \%$ & $0.017 \%$ & 1.06 & 0.91 & $0.019 \%$ & $0.100 \%$ & $0.076 \%$ & $0.028 \%$ & -0.70 & -1.13 \\
\hline$q^{M "}$ & $0.034 \%$ & $0.290 \%$ & $0.082 \%$ & $0.052 \%$ & 2.46 & 6.45 & $0.034 \%$ & $0.126 \%$ & $0.062 \%$ & $0.018 \%$ & 1.11 & 1.13 & $0.035 \%$ & $0.290 \%$ & $0.125 \%$ & $0.072 \%$ & 1.07 & 0.34 \\
\hline
\end{tabular}




\section{Table 4 Properties and correlations of residential property returns and macroeconomic variables}

This table shows the basic properties of the variables, which we use to analyze S\&P/Case-Shiller home price returns from February 1993 to August 2012 . The returns are the average monthly aggregated indices of each Metropolitan Statistical Areas. Correlation $d$ represents the dwelling benefits, $q^{M}$ means the normalized illiquidity costs for whole residential property market, and CS represents the credit spread we calculate using the bond yield difference between Moody's Aaa and Baa rated corporate bonds. TS represents the term spread calculated with the difference in rates between a 10-year Treasury bond and a 3-monthTreasury bill. CPI, IP and UNE represent the Consumer Price Index change, industrial production change and unemployment rate change, respectively. MRTG RT represents 30-year conventional mortgage rate. These macroeconomic variables come from St. Louis FRB Economic Data. SENTBUY and SENTSEL depict consumer sentiment indices on buying and selling a house, respectively. These sentiment indices are normalized to zero mean and unit variance, and then multiplied by 100 . The sentiment indices are provided from the University of Michigan.

\begin{tabular}{|c|c|c|c|c|c|c|c|c|c|c|c|c|c|c|c|c|c|c|c|c|c|}
\hline & \multirow{2}{*}{$\begin{array}{l}\text { Mean\% } \\
\text { (A) }\end{array}$} & \multirow{2}{*}{$\begin{array}{l}\text { Std. } \\
\text { Dev. } \\
\text { (B) }\end{array}$} & \multirow{2}{*}{$\begin{array}{c}\text { Skew- } \\
\text { ness }\end{array}$} & \multirow{2}{*}{$\begin{array}{c}\text { Kurt- } \\
\text { osis }\end{array}$} & \multirow{2}{*}{$\begin{array}{c}\text { Annual } \\
\text { Sharpe } \\
\text { ratio } \\
(=\mathrm{A} / \mathrm{B})\end{array}$} & \multirow{2}{*}{$\begin{array}{l}1 \mathrm{st} \\
\text { order } \\
\text { auto- } \\
\text { correl } \\
\text { ation }\end{array}$} & \multicolumn{15}{|c|}{ Correlations } \\
\hline & & & & & & & $r^{H}$ & $r^{L}$ & $r^{H}+d$ & $r^{L}+d$ & $\begin{array}{c}r^{H}+d- \\
q^{H}\end{array}$ & $\begin{array}{c}r^{L}+d- \\
q^{L}\end{array}$ & $d$ & $q^{M}$ & $\mathrm{CS}$ & $\mathrm{TS}$ & CPI & IP & UNE & $\begin{array}{l}\text { SENT } \\
\text { BUY }\end{array}$ & $\begin{array}{c}\text { SENT } \\
\text { SEL }\end{array}$ \\
\hline$r^{H}$ & 0.281 & 0.89 & -1.03 & 1.93 & 1.10 & 0.913 & 1 & & & & & & & & & & & & & & \\
\hline$r^{L}$ & 0.262 & 1.26 & -1.53 & 2.85 & 0.72 & 0.911 & 0.90 & 1 & & & & & & & & & & & & & \\
\hline$r^{H}+d$ & 0.639 & 0.89 & -1.08 & 1.99 & 2.50 & 0.913 & 0.998 & 0.90 & 1 & & & & & & & & & & & & \\
\hline$r^{L}+d$ & 0.620 & 1.26 & -1.56 & 2.87 & 1.70 & 0.911 & 0.90 & 0.999 & 0.90 & 1 & & & & & & & & & & & \\
\hline$r^{H}+d-q^{H}$ & 0.533 & 0.91 & -1.37 & 2.46 & 2.02 & 0.921 & 0.99 & 0.91 & 0.996 & 0.92 & 1 & & & & & & & & & & \\
\hline$r^{L}+d-q^{L}$ & 0.566 & 1.27 & -1.60 & 2.93 & 1.54 & 0.912 & 0.90 & 0.999 & 0.90 & 1.00 & 0.91 & 1 & & & & & & & & & \\
\hline$d$ & 0.358 & 0.05 & -0.91 & -0.60 & & 0.996 & -0.04 & -0.03 & 0.02 & 0.01 & 0.02 & 0.01 & 1 & & & & & & & & \\
\hline$q^{M}$ & 0.084 & 0.07 & 1.68 & 2.27 & & 0.893 & -0.41 & -0.54 & -0.41 & -0.54 & -0.49 & -0.56 & 0.01 & 1 & & & & & & & \\
\hline $\mathrm{CS}$ & 0.968 & 0.45 & 2.93 & 10.68 & & 0.962 & -0.47 & -0.53 & -0.47 & -0.53 & -0.51 & -0.54 & -0.08 & 0.62 & 1 & & & & & & \\
\hline TS & 1.805 & 1.16 & -0.14 & -1.19 & & 0.973 & -0.03 & -0.08 & -0.02 & -0.07 & -0.04 & -0.08 & 0.22 & 0.23 & 0.32 & 1 & & & & & \\
\hline CPI & 0.205 & 0.35 & -1.18 & 6.63 & & 0.456 & 0.17 & 0.04 & 0.17 & 0.04 & 0.16 & 0.03 & -0.07 & -0.04 & -0.25 & -0.06 & 1 & & & & \\
\hline IP & 0.177 & 0.69 & -1.69 & 7.97 & & 0.225 & 0.27 & 0.34 & 0.27 & 0.35 & 0.29 & 0.35 & 0.13 & -0.32 & -0.44 & 0.00 & 0.03 & 1 & & & \\
\hline UNE & 5.949 & 1.72 & 1.03 & -0.02 & & 0.971 & -0.24 & -0.28 & -0.22 & -0.27 & -0.25 & -0.27 & 0.30 & 0.38 & 0.42 & 0.67 & -0.02 & 0.01 & 1 & & \\
\hline SENTBUY & -0.316 & 100.1 & -0.56 & 2.64 & & 0.974 & 0.41 & 0.40 & 0.44 & 0.42 & 0.45 & 0.42 & 0.55 & -0.27 & -0.26 & 0.38 & 0.01 & 0.25 & 0.08 & 1 & \\
\hline SENTSEL & 0.226 & 100.2 & -0.68 & 1.91 & & 0.992 & 0.60 & 0.64 & 0.59 & 0.64 & 0.64 & 0.64 & -0.15 & -0.62 & -0.56 & -0.37 & 0.07 & 0.16 & -0.77 & 0.33 & 1 \\
\hline MRTG_RT & 6.516 & 1.25 & -0.24 & 2.49 & & 0.974 & 0.17 & 0.21 & 0.19 & 0.22 & 0.23 & 0.23 & 0.25 & -0.48 & -0.50 & -0.32 & 0.04 & 0.12 & -0.66 & 0.17 & 0.62 \\
\hline
\end{tabular}




\section{Table 5 Illiquidity risks in residential property markets}

This table shows the properties of illiquidity risks. $\beta^{1}$ is the conventional CAPM beta measured by $\operatorname{Cov}(r+$ $\left.d, r^{M}+d\right)$ with respect to market return variance $\left(\operatorname{Var}\left(r^{M}+d-q^{M}\right)\right)$, and the other betas represent the illiquidity risks. $\beta^{2}$ represents the commonality in illiquidity with the market $\left(\operatorname{Cov}\left(q, q^{M}\right)\right)$ with respect to the variance, $\beta^{3}$ means the illiquidity sensitivity to market returns $\left(\operatorname{Cov}\left(q, r^{M}+d\right)\right)$ with respect to the variance, and $\beta^{4}$ represents the return sensitivity to market illiquidity $\left(\operatorname{Cov}\left(r+d, q^{M}\right)\right)$ with respect to the variance . $\beta^{\text {Net }}$ is the aggregated beta defined as $\beta^{1}+\beta^{2}-\beta^{3}-\beta^{4}$. $\beta^{\text {Illiq }}$ is the aggregated beta for the illiquidity risks, defined as $\beta^{2}-\beta^{3}-\beta^{4}$, and represents the effects of aggregated illiquidity risks on property returns. E(q) and Std. Dev. (q) represent the average and standard deviation of the illiquidity costs, respectively. The numbers in parentheses are t-values.

\begin{tabular}{|c|c|c|c|c|c|c|c|c|}
\hline & $\beta^{l}$ & $\beta^{2}$ & $\beta^{3}$ & $\beta^{4}$ & $\beta^{N e t}$ & $\beta^{\text {Illiq }}$ & $E(q)$ & $\begin{array}{c}\text { Std. } \\
\text { Dev. (q) }\end{array}$ \\
\hline \multicolumn{9}{|l|}{ A. Entire Period } \\
\hline Liquid properties & $\begin{array}{c}1.153 \\
(15.36)\end{array}$ & 0.002 & -0.006 & $\begin{array}{c}-0.047 \\
(-10.77)\end{array}$ & $\begin{array}{c}1.207 \\
(15.85)\end{array}$ & $\begin{array}{c}0.054 \\
(12.93)\end{array}$ & 0.054 & 0.031 \\
\hline Medium properties & $\begin{array}{c}0.927 \\
(17.52)\end{array}$ & 0.005 & -0.030 & $\begin{array}{c}-0.031 \\
(-10.35)\end{array}$ & $\begin{array}{c}0.992 \\
(18.62)\end{array}$ & $\begin{array}{c}0.065 \\
(22.73)\end{array}$ & 0.084 & 0.069 \\
\hline Illiquid properties & $\begin{array}{c}0.841 \\
(21.22)\end{array}$ & 0.006 & -0.028 & $\begin{array}{l}-0.025 \\
(-9.02)\end{array}$ & $\begin{array}{c}0.900 \\
(22.18)\end{array}$ & $\begin{array}{c}0.059 \\
(22.12)\end{array}$ & 0.106 & 0.088 \\
\hline Illiquid - Liquid & $\begin{array}{l}-0.311 \\
(-6.86)\end{array}$ & 0.004 & -0.023 & $\begin{array}{l}0.022 \\
(9.7)\end{array}$ & $\begin{array}{l}-0.307 \\
(-6.51)\end{array}$ & $\begin{array}{l}0.005 \\
(2.11)\end{array}$ & & \\
\hline \multicolumn{9}{|l|}{ B. Bull markets } \\
\hline Liquid properties & $\begin{array}{l}1.062 \\
(6.85)\end{array}$ & 0.004 & 0.045 & $\begin{array}{l}0.047 \\
(7.13)\end{array}$ & $\begin{array}{l}0.974 \\
(6.73)\end{array}$ & $\begin{array}{c}-0.088 \\
(-13.71)\end{array}$ & 0.043 & 0.023 \\
\hline Medium properties & $\begin{array}{l}1.113 \\
(7.53)\end{array}$ & 0.005 & 0.056 & $\begin{array}{l}0.057 \\
(7.01)\end{array}$ & $\begin{array}{l}1.004 \\
(7.36)\end{array}$ & $\begin{array}{c}-0.108 \\
(-13.79)\end{array}$ & 0.056 & 0.030 \\
\hline Illiquid properties & $\begin{array}{l}1.161 \\
(10.2)\end{array}$ & 0.008 & 0.095 & $\begin{array}{l}0.062 \\
(9.12)\end{array}$ & $\begin{array}{l}1.012 \\
(9.66)\end{array}$ & $\begin{array}{c}-0.150 \\
(-22.58)\end{array}$ & 0.070 & 0.050 \\
\hline Illiquid - Liquid & $\begin{array}{l}0.099 \\
(2.03)\end{array}$ & 0.004 & 0.051 & $\begin{array}{r}0.015 \\
(6.1) \\
\end{array}$ & $\begin{array}{c}0.038 \\
(0.8)\end{array}$ & $\begin{array}{c}-0.061 \\
(-25.08)\end{array}$ & & \\
\hline \multicolumn{9}{|l|}{ C. Bear markets } \\
\hline Liquid properties & $\begin{array}{c}1.170 \\
(10.96)\end{array}$ & 0.001 & -0.005 & $\begin{array}{l}-0.043 \\
(-8.12)\end{array}$ & $\begin{array}{c}1.219 \\
(11.38)\end{array}$ & $\begin{array}{c}0.049 \\
(9.6)\end{array}$ & 0.078 & 0.031 \\
\hline Medium properties & $\begin{array}{c}0.894 \\
(14.49)\end{array}$ & 0.005 & -0.027 & $\begin{array}{l}-0.027 \\
(-9.6)\end{array}$ & $\begin{array}{c}0.953 \\
(15.54)\end{array}$ & $\begin{array}{l}0.059 \\
(21.7)\end{array}$ & 0.143 & 0.089 \\
\hline Illiquid properties & $\begin{array}{c}0.826 \\
(18.17)\end{array}$ & 0.005 & -0.022 & $\begin{array}{c}-0.025 \\
(-10.93)\end{array}$ & $\begin{array}{c}0.877 \\
(19.23)\end{array}$ & $\begin{array}{c}0.052 \\
(23.43)\end{array}$ & 0.183 & 0.102 \\
\hline Illiquid - Liquid & $\begin{array}{l}-0.345 \\
(-4.56)\end{array}$ & 0.004 & -0.017 & $\begin{array}{l}0.018 \\
(5.07)\end{array}$ & $\begin{array}{l}-0.342 \\
(-4.38)\end{array}$ & $\begin{array}{l}0.003 \\
(0.82)\end{array}$ & & \\
\hline
\end{tabular}




\section{Table 6 Pooled regression results with the normalized illiquidity cost measure}

This table reports the regression results on the difference between $r_{t}^{H}$ and $r_{t}^{L}$ for the entire period and two sub-periods. The market represents the average of the aggregated Case-Shiller index returns for each Metropolitan Statistical Area, which is the excess return to the risk-free rate and includes the dwelling benefits. The variable $q^{M}$ means the market illiquidity costs, which are normalized by three different methods, denoted as $q, q^{\prime}$, and $q^{\prime \prime}$. The numbers in parentheses are t-values based on the coefficient covariance using the White cross-section method.

\begin{tabular}{|c|c|c|c|c|c|c|c|c|c|}
\hline \multirow[b]{2}{*}{ Variable } & \multicolumn{3}{|c|}{ Entire Period } & \multicolumn{3}{|c|}{ Bull Markets } & \multicolumn{3}{|c|}{ Bear Markets } \\
\hline & $q$ & $q^{\prime}$ & $q^{\prime \prime}$ & $q$ & $q^{\prime}$ & $q^{\prime \prime}$ & $q$ & $q^{\prime}$ & $q^{\prime \prime}$ \\
\hline \multirow[t]{2}{*}{$\alpha$} & -0.625 & -0.617 & -0.554 & -1.854 & -1.741 & -2.006 & -2.277 & -2.226 & -2.265 \\
\hline & $(-1.45)$ & $(-1.45)$ & $(-1.25)$ & $(-4.86)$ & $(-4.57)$ & $(-5.28)$ & $(-0.85)$ & $(-0.85)$ & $(-0.84)$ \\
\hline \multirow[t]{2}{*}{ Market } & -0.329 & -0.339 & -0.300 & 0.047 & 0.040 & 0.047 & -0.516 & -0.515 & -0.515 \\
\hline & $(-4.27)$ & $(-4.4)$ & $(-3.96)$ & $(0.4)$ & $(0.35)$ & $(0.4)$ & $(-2.92)$ & $(-2.91)$ & $(-2.91)$ \\
\hline \multirow[t]{2}{*}{$q^{M}$} & 2.891 & 2.668 & 3.360 & 3.162 & 2.540 & 5.270 & 0.831 & 1.132 & 0.428 \\
\hline & (3.44) & $(4.00)$ & $(2.73)$ & $(2.51)$ & $(2.80)$ & $(2.51)$ & $(0.51)$ & $(0.87)$ & $(0.22)$ \\
\hline \multirow[t]{2}{*}{$\mathrm{CS}$} & 0.116 & 0.121 & 0.112 & -0.137 & -0.139 & -0.137 & 0.222 & 0.220 & 0.233 \\
\hline & $(1.05)$ & (1.16) & $(0.96)$ & $(-1.45)$ & $(-1.44)$ & $(-1.45)$ & $(1.32)$ & (1.38) & (1.36) \\
\hline \multirow[t]{2}{*}{$\mathrm{TS}$} & 0.025 & 0.025 & 0.029 & -0.057 & -0.056 & -0.057 & -0.143 & -0.126 & -0.155 \\
\hline & $(0.69)$ & $(0.69)$ & $(0.76)$ & $(-2.01)$ & $(-2.04)$ & $(-2.01)$ & $(-0.56)$ & $(-0.49)$ & $(-0.61)$ \\
\hline \multirow[t]{2}{*}{ CPI } & 0.205 & 0.200 & 0.202 & 0.007 & 0.006 & 0.007 & 0.360 & 0.361 & 0.356 \\
\hline & $(2.07)$ & $(2.07)$ & $(2.03)$ & $(0.15)$ & $(0.12)$ & $(0.15)$ & $(1.86)$ & $(1.88)$ & $(1.8)$ \\
\hline \multirow[t]{2}{*}{ IP } & -0.027 & -0.023 & -0.025 & 0.001 & 0.001 & 0.001 & 0.034 & 0.034 & 0.037 \\
\hline & $(-0.74)$ & $(-0.64)$ & $(-0.72)$ & $(0.04)$ & $(0.07)$ & $(0.04)$ & $(0.35)$ & $(0.35)$ & $(0.39)$ \\
\hline \multirow[t]{2}{*}{ UNE } & 0.031 & 0.034 & 0.017 & 0.141 & 0.141 & 0.141 & 0.037 & 0.049 & 0.021 \\
\hline & $(0.62)$ & $(0.68)$ & $(0.33)$ & (3.9) & $(3.92)$ & (3.9) & $(0.21)$ & $(0.28)$ & $(0.12)$ \\
\hline \multirow[t]{2}{*}{ SENTBUY } & 0.000 & 0.000 & 0.000 & 0.001 & 0.001 & 0.001 & 0.005 & 0.004 & 0.005 \\
\hline & $(1.21)$ & $(1.16)$ & $(1.25)$ & $(2.51)$ & $(2.41)$ & $(2.51)$ & $(0.96)$ & $(0.9)$ & $(1.03)$ \\
\hline \multirow[t]{2}{*}{ SENTSEL } & 0.001 & 0.001 & 0.000 & 0.001 & 0.001 & 0.001 & -0.005 & -0.004 & -0.007 \\
\hline & $(0.57)$ & $(0.78)$ & $(0.05)$ & (1.18) & $(1.2)$ & (1.18) & $(-0.65)$ & $(-0.49)$ & $(-0.79)$ \\
\hline \multirow[t]{2}{*}{ Cold season } & -0.118 & -0.114 & -0.115 & 0.044 & 0.042 & 0.044 & -0.370 & -0.383 & -0.348 \\
\hline & $(-1.7)$ & $(-1.66)$ & $(-1.64)$ & $(0.91)$ & $(0.9)$ & $(0.91)$ & $(-1.26)$ & $(-1.35)$ & $(-1.18)$ \\
\hline \multirow[t]{2}{*}{ MRTG_RT } & 0.033 & 0.035 & 0.027 & 0.118 & 0.113 & 0.118 & 0.349 & 0.339 & 0.356 \\
\hline & $(0.83)$ & $(0.91)$ & $(0.68)$ & $(3.56)$ & $(3.51)$ & $(3.56)$ & $(1.38)$ & $(1.37)$ & (1.39) \\
\hline \multirow[t]{2}{*}{$\mathrm{AR}(1)$} & 0.426 & 0.424 & 0.430 & 0.272 & 0.271 & 0.272 & 0.466 & 0.463 & 0.469 \\
\hline & $(11.55)$ & (11.54) & (11.55) & $(10.32)$ & $(10.3)$ & $(10.32)$ & $(8.76)$ & $(8.78)$ & $(8.82)$ \\
\hline \multirow[t]{2}{*}{$\mathrm{AR}(3)$} & -0.186 & -0.186 & -0.187 & -0.226 & -0.226 & -0.226 & -0.183 & -0.182 & -0.184 \\
\hline & $(-5.85)$ & $(-5.86)$ & $(-5.79)$ & $(-9.7)$ & $(-9.65)$ & $(-9.7)$ & $(-4.1)$ & $(-4.09)$ & $(-4.12)$ \\
\hline \multirow[t]{2}{*}{ AR(12) } & 0.046 & 0.047 & 0.044 & 0.079 & 0.078 & 0.079 & 0.031 & 0.031 & 0.031 \\
\hline & (1.63) & $(1.65)$ & $(1.56)$ & $(3.37)$ & $(3.36)$ & $(3.37)$ & $(0.79)$ & $(0.78)$ & $(0.79)$ \\
\hline Adj. $R^{2}$ & $28.1 \%$ & $28.3 \%$ & $27.9 \%$ & $15.1 \%$ & $15.1 \%$ & $15.1 \%$ & $28.7 \%$ & $28.8 \%$ & $28.7 \%$ \\
\hline
\end{tabular}




\section{Figure 1 Trends of the Amihud measure and the normalized illiquidity costs}

Figure 1 shows the dynamics of the Amihud measure and the three normalized market illiquidity costs over time. The illiquidity increases sharply during the recent bear market. The first method aims for normalized illiquidity costs to have the same means with the estimated average illiquidity costs. The second method would generate less volatile and lower illiquidity costs due to the smaller sensitivities on the Amihud measure, whereas the third method generates more volatile and larger illiquidity costs. The three normalized market illiquidity costs are plotted along the left axis, whereas the Amihud measure is plotted along right axis.

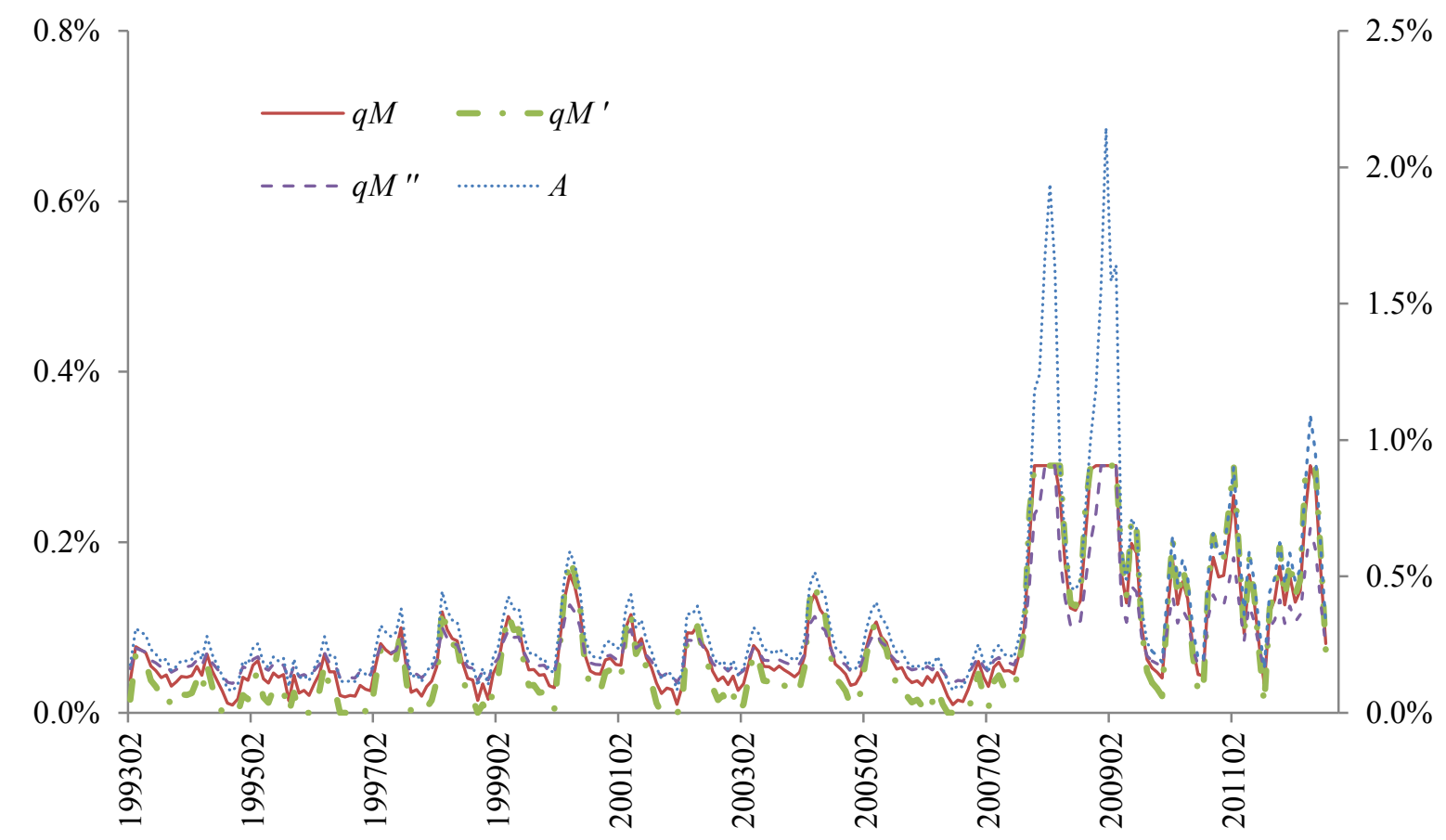




\section{Figure 2 Seasonal patterns in residential property markets}

Figure 2 illustrates the seasonal patterns of residential property markets. The horizontal axis represents each month. In panel A, the seasonality in illiquidity does not matter when housing markets are in boom: only when housing markets are in recession, then illiquidity increases significantly during the cold season. Sales pair counts, property returns and $I M L \mathrm{~s}$ show seasonal patterns, and the variation of patterns becomes larger during bear markets. In particular, during bull markets, the average property returns are positive every month, and are high during the hot season in panel C. During bear markets, however, the average market returns are positive only during the hot season.

A. Monthly average illiquidity costs

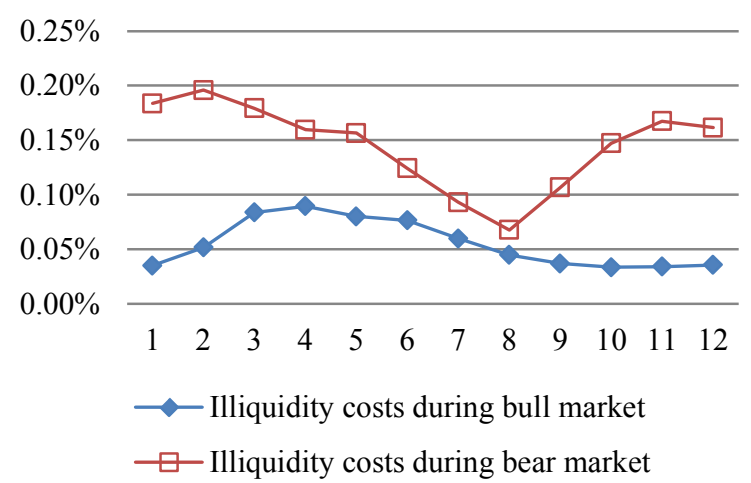

C. Monthly average property returns

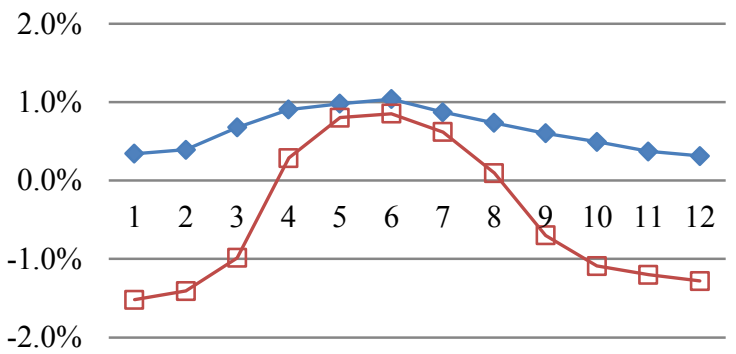

$\longrightarrow$ Market return during bull market

$\square$ Market return during bear market
B. Monthly average sales pair counts

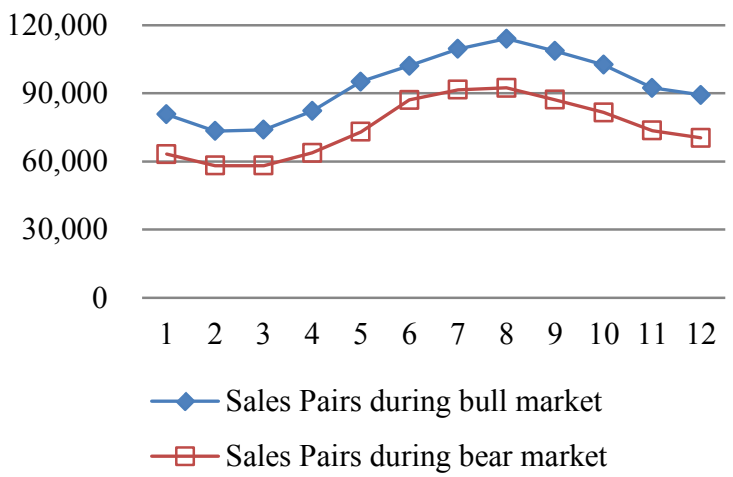

D. Monthly average $I M L s$

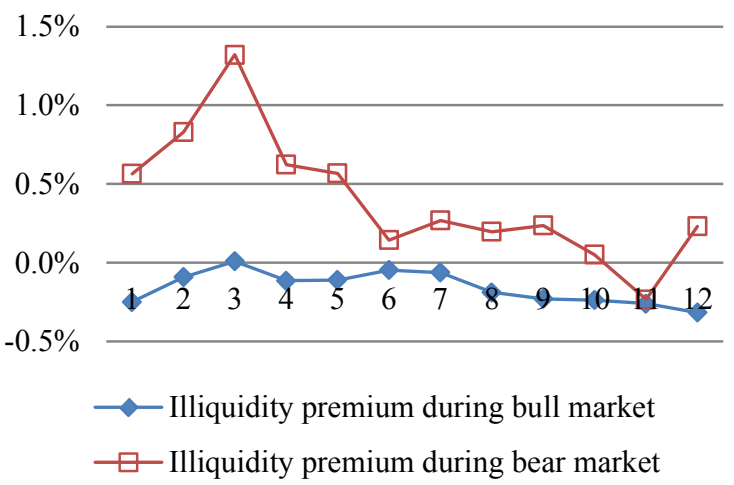

